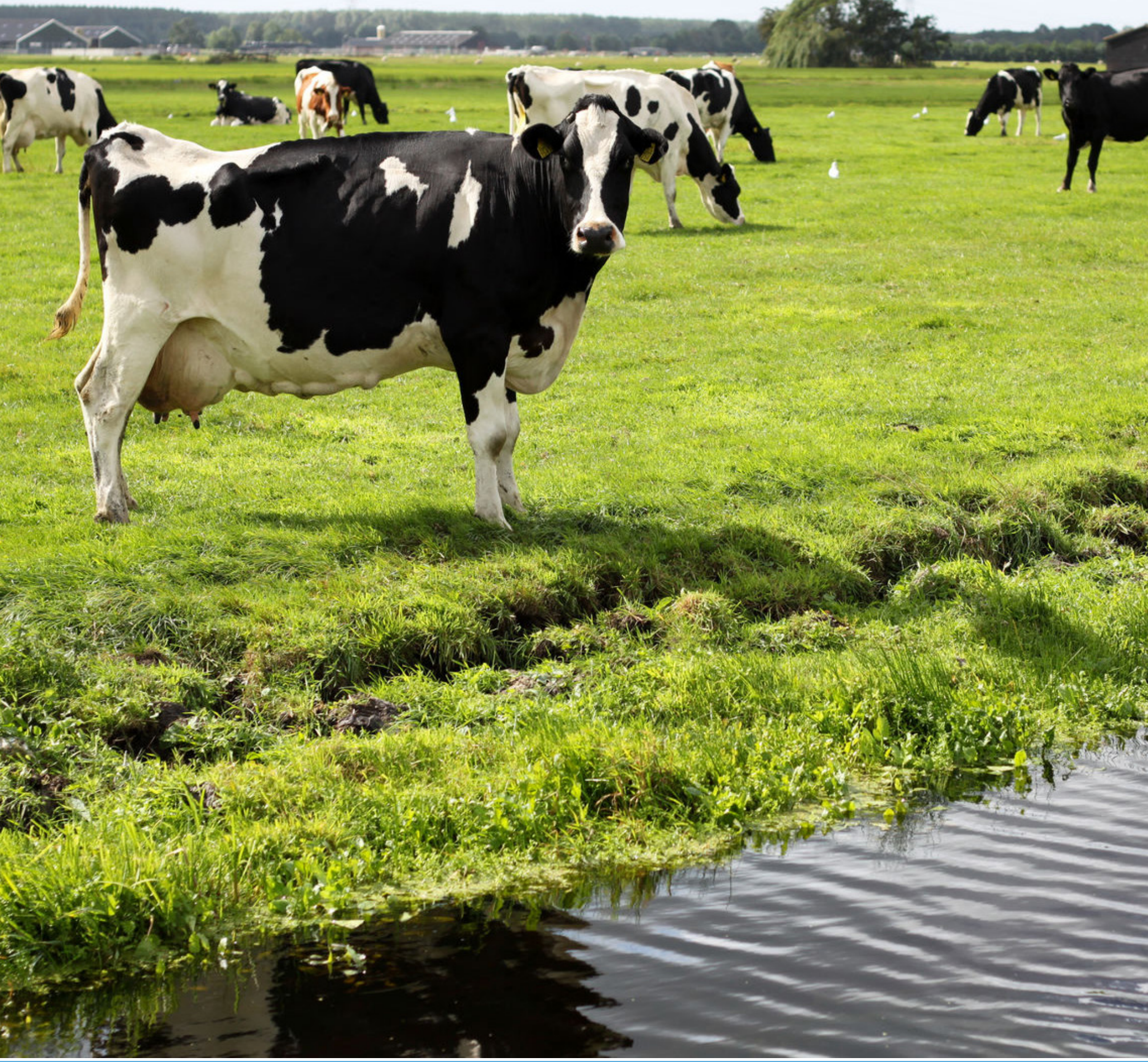

KringloopWijzer nader bekeken

Toepasbaarheid van de Kringloopwijzer voor melkveebedrijven die duidelijk verschillen van het gemiddelde Nederlandse melkveebedrijf, waaronder bedrijven met een extensieve bedrijfsvoering 



\section{KringloopWijzer nader bekeken}

Toepasbaarheid van de Kringloopwijzer voor melkveebedrijven die duidelijk verschillen van het gemiddelde Nederlandse melkveebedrijf, waaronder bedrijven met een extensievere bedrijfsvoering.

L. Šebek ${ }^{1}$, H. van Schooten ${ }^{1}$, B. Bassa ${ }^{2}$ en C. van Dijk ${ }^{2}$

${ }^{1}$ Wageningen Livestock Research

2 Projecten LTO Noord

Dit onderzoek is uitgevoerd door Wageningen Livestock Research en Projecten LTO Noord, in opdracht van LTO Noord en gefinancierd door het Melkveefonds en de LTO Noord Fondsen.

Wageningen Livestock Research

Wageningen, Juni 2018 
L. Šebek, H. van Schooten, B. Bassa en C. van Dijk, 2018. KringloopWijzer nader bekeken; Toepasbaarheid KringloopWijzer voor niet-gemiddelde melkveebedrijven waaronder bedrijven met extensievere bedrijfsvoering. Wageningen Livestock Research, Report 1110.

Dit rapport is gratis te downloaden op https://doi.org/10.18174/452482 of op www.wur.nl/livestock-research (onder Wageningen Livestock Research publicaties).

(C) 2018 Wageningen Livestock Research

Postbus 338, 6700 AH Wageningen, T 03174839 53, E info.livestockresearch@wur.nl, www.wur.nl/livestock-research. Wageningen Livestock Research is onderdeel van Wageningen University \& Research.

Wageningen Livestock Research aanvaardt geen aansprakelijkheid voor eventuele schade voortvloeiend uit het gebruik van de resultaten van dit onderzoek of de toepassing van de adviezen.

Alle rechten voorbehouden. Niets uit deze uitgave mag worden vermenigvuldigd en/of openbaar gemaakt worden door middel van druk, fotokopie, microfilm of op welke wijze dan ook zonder voorafgaande toestemming van de uitgever of auteur.

Wageningen Livestock Research is NEN-EN-ISO 9001:2015 gecertificeerd.

Op al onze onderzoeksopdrachten zijn de Algemene Voorwaarden van de Animal Sciences Group van toepassing. Deze zijn gedeponeerd bij de Arrondissementsrechtbank Zwolle. 


\section{Inhoud}

$\begin{array}{ll}\text { Woord vooraf } & 7\end{array}$

$\begin{array}{ll}\text { Samenvatting en conclusies } & 8\end{array}$

$\begin{array}{lll}1 & \text { Inleiding } & 11\end{array}$

$\begin{array}{lll}1.1 & \text { Achtergrond } & 11\end{array}$

1.2 Doel en doelgroep 11

2

$\begin{array}{ll}\text { Aanpak } & 13\end{array}$

$\begin{array}{lll}2.1 & \text { Werving en selectie van deelnemende bedrijven } & 13\end{array}$

2.2 Praktijksessies met deelnemende bedrijven 13

$\begin{array}{lll}2.3 & \text { Gevoeligheidsanalyse } & 13\end{array}$

2.4 Verbetermogelijkheden technische KLW-kengetallen $\quad 13$

$\begin{array}{lll}2.5 & \text { KLW-kengetallen voor maatschappelijke waarde } & 14\end{array}$

$\begin{array}{ll}\text { Resultaten praktijksessies } & 15\end{array}$

$\begin{array}{lll}3.1 & \text { Algemeen } & 15\end{array}$

3.2 Inventarisatie drijfveren en onderwerpen van deelnemers $\quad 15$

3.2.1 Drijfveren deelnemers $\quad 15$

$\begin{array}{ll}3.2 .2 & \text { Onderwerpen van deelnemers }\end{array}$

$\begin{array}{lll}3.3 & \text { Technische kengetallen } & 17\end{array}$

$\begin{array}{ll}\text { 3.3.1 Overzicht resultaten } & 17\end{array}$

3.3.2 Toelichting aangedragen mogelijkheden voor verbetering 17

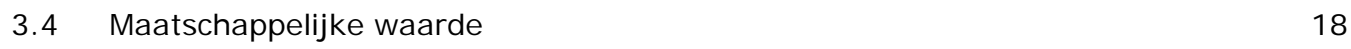

$\begin{array}{ll}3.4 .1 \text { Overzicht resultaten } & 18\end{array}$

$\begin{array}{ll}3.4 .2 \text { Toelichting } & 19\end{array}$

$\begin{array}{lll}3.5 & \text { Samenvatting resultaat praktijksessies } & 21\end{array}$

4

Gevoeligheidsanalyse $\quad 22$

$\begin{array}{lll}4.1 & \text { Algemeen } & 22\end{array}$

$\begin{array}{lll}4.2 & \text { Werkwijze } & 22\end{array}$

$\begin{array}{lll}4.3 & \text { Resultaten } & 23\end{array}$

4.3.1 Analyse voor het gemiddelde Nederlandse bedrijf 23

4.3.2 Analyse voor het gemiddelde 'extensieve' bedrijf 23

4.3.3 Analyse voor het individuele bedrijf 23

$\begin{array}{lll}4.4 & \text { Samenvatting gevoeligheidsanalyse } & 25\end{array}$

$5 \quad$ Mogelijkheden tot verbetering KLW $\quad 27$

$\begin{array}{lll}5.1 & \text { Algemeen } & 27\end{array}$

$\begin{array}{lll}5.2 & \text { VEM-behoefte } & 27\end{array}$

$\begin{array}{lll}5.3 & \text { Diergewicht } & 27\end{array}$

$\begin{array}{lll}5.4 & \text { P-gehalte melk } & 28\end{array}$

5.4.1 Algemeen $\quad 28$

5.4.2 P-melk op basis van de actuele melksamenstelling 28

5.4.3 P-melk per ras $\quad 29$

5.5 Samenstelling vers gras $\quad 29$

5.6 Samenvatting verbetering KLW $\quad 32$

Bijlage 1 Gevoeligheidsanalyse gemiddelde Nederlandse melkveebedrijf 
Bijlage 2 Gevoeligheidsanalyse gemiddelde 'extensieve' melkveebedrijf 34

Bijlage 3 Gevoeligheidsanalyse individuele 'extensieve' melkveebedrijf 35 


\section{Woord vooraf}

Het instrument KringloopWijzer (KLW) geeft op basis van bedrijfseigen data diverse overzichten en kengetallen. De melkveehouder kan hiermee zowel het bedrijfsmanagement als het omgaan met de mineralenkringloop verbeteren. Daarmee kunnen milieukundige voordelen gecombineerd worden met bedrijfseconomische optimalisatie. De KLW bestaat uit diverse rekenkernen waarbij de $\mathrm{N}, \mathrm{P}, \mathrm{NH}_{3}$ en $\mathrm{C}$ worden meegenomen. De centrale motor is de Bedrijfsspecifieke Excretie (BEX).

Binnen het werkgebied van LTO Noord komt met regelmaat het signaal naar voren dat melkveehouders de prestaties van het eigen bedrijf niet goed herkennen in de resultaten van de KLW. Samen met melkveehouders uit meerdere provincies is gekeken naar de KLW in alle facetten van het instrument. Tevens is gekeken naar indicatoren met een maatschappelijk belang. Zonder de open houding en bereidwilligheid van de deelnemende melkveehouders om bedrijfsgegevens beschikbaar te stellen, informatie te delen, mee te discussiëren en niet in de laatste plaats ook aan zelfreflectie te doen was deze rapportage niet tot stand gekomen.

Met de uitkomsten van dit project is het mogelijk de toepasbaarheid en bedrijfsspecifieke herkenbaarheid van de KLW te verbeteren. Vooruitlopend op deze rapportage zijn de uitkomsten van dit project gedeeld met de KLW-werkgroep 'Doorontwikkelen KLW'. 


\title{
Samenvatting en conclusies
}

\begin{abstract}
Algemeen
Bij de ontwikkeling van de KringloopWijzer (KLW) is gekeken of de KLW bruikbaar is voor (een goede afspiegeling van) de melkveesector. Bij validatie door de Commissie van Deskundigen Meststoffenwet (CDM) bleek dat de betrouwbaarheid en nauwkeurigheid van de met de KLW berekende kengetallen voor ongeveer $80 \%$ van de Nederlandse melkveebedrijven voldoende geborgd is. In het project dat in dit rapport wordt beschreven is gewerkt met bedrijven die niet tot die $80 \%$ behoren. De deelnemende bedrijven zijn onder één noemer gebracht via de aanduiding 'extensieve' bedrijven, ondanks dat deze vlag de lading niet goed dekt (bijvoorbeeld als met extensief een lage melkproductie per hectare wordt bedoeld). Het zijn ook bedrijven die weinig of geen snijmais voeren, die veel weiden of die een ander veeslag dan HF op het bedrijf hebben. Het zijn veelal bedrijven die naar verhouding 'dataextensief' zijn, omdat voor de specifieke onderdelen van de bedrijfsvoering die in hun situatie het kenmerkende verschil maken geen bedrijfsspecifieke data beschikbaar zijn. In plaats daarvan worden forfaits gebruikt die flink kunnen afwijken van de werkelijke prestatie.
\end{abstract}

Het project had twee doelen:

- Technische aspecten: De vraag of de door de KLW berekende resultaten recht doen aan de werkelijke resultaten van deze bedrijven, eventuele afwijkingen identificeren en mogelijkheden voor verbetering aangeven.

- Maatschappelijke waarde: De vraag of er KLW kengetallen zijn die gebruikt kunnen worden als maat voor de maatschappelijk waarde van het melkveebedrijf.

De opzet van het project was dat initiatief en sturing voornamelijk bij de deelnemende veehouders moest liggen. Hiervoor zijn drie praktijksessies georganiseerd. Het resultaat van de praktijksessies is dat er speciale aandacht te besteden is aan:

- Technische aspecten

o Vers gras: samenstelling (gehalte VEM, $\mathrm{N}$ en $\mathrm{P}$ ) en opname

o VEM opname: VEM-behoefte (ras/gewicht en tussenkalftijd) en VEM-dekking

o P-gehalte melk

- Maatschappelijke waarde

o Identificatie maatschappelijke waarde

o Koppeling aan technische kengetallen KLW

o Gebruik KLW

\section{Technische aspecten}

Identificatie verbeterpunten

Voor de technische aspecten is in de praktijksessies de aanpak gekozen om via een concrete gevoeligheidsanalyse (betrekking hebbend op het eigen bedrijf) te identificeren of en zo ja op welke punten de KLW tot waarden voor één of meerdere kengetallen komt die niet aansluiten bij de eigen praktijkwaarnemingen en vervolgens na te gaan of er verbetermogelijkheden zijn. Voor de gevoeligheidsanalyse zijn 8 parameters benoemd waarvan verwacht werd dat ze een grote invloed hebben op de berekening van de KLW-kengetallen. Voor 5 van die parameters bleek de verwachting juist te zijn. Het betreft de VEM-dekking, het P-gehalte van melk, het diergewicht en het $\mathrm{N}$ - en Pgehalte van vers gras (N/VEM gras en P/VEM gras). Via aanpassing van de vaststelling en/of berekening van deze 5 parameters kan de KLW verbeterd worden voor 'extensieve' bedrijven. Daarmee bleek uit de gevoeligheidsanalyse dat de KringloopWijzer inderdaad tot een niet bij de praktijk aansluitend resultaat voor KLW-kengetallen kwam voor de in dit project deelnemende 'extensieve' bedrijven. Het betreft vooral de kengetallen van de BEX en de berekende grasopbrengst. 
Ook het bodemoverschot, de maisopbrengst en de ammoniakemissie lieten verschillen zien. Het aantal kengetallen dat afweek en de grootte van de afwijking verschilde per bedrijf. Voor de deelnemende bedrijven is in dit project geen duidelijke relatie gezien tussen een geconstateerde afwijking en het bedrijfstype of de beweidingsintensiteit. Een uitzondering was het geschatte $\mathrm{N}$ - en P-gehalte van vers gras, waarvoor een mogelijke relatie met beweidingsintensiteit werd gezien. Afwijkende kengetallen kunnen verwacht worden voor bedrijven met veel vers gras in het rantsoen en waarbij de relatie tussen de samenstelling van vers gras en de samenstelling van graskuil afwijkt van het Nederlandse gemiddelde. Daarnaast kunnen afwijkingen verwacht worden voor bedrijven met een ander type vee dan HF met name als gevolg van een afwijkend diergewicht of een ander P-gehalte in de melk dan in de KLW als standaard wordt gebruikt.

Opties voor verbetering technische aspecten

De resultaten van de KLW kunnen verbeterd worden door de vaststelling en/of berekening van de volgende 5 parameters aan te passen:

- VEM-behoefte

- Diergewicht

- P-gehalte melk

- $\quad \mathrm{N}$-gehalte vers gras

- P-gehalte vers gras

VEM-behoefte: De mogelijkheden voor verbetering van de VEM-behoefte-berekening voor melktypische rassen zijn inmiddels belegd in een project dat zich richt op HF koeien. De mogelijkheden voor verbetering voor de dubbeldoelrassen zijn geïdentificeerd en kunnen projectmatig worden aangepakt.

Diergewicht: Het diergewicht heeft een duidelijk invloed op de door de KLW berekende kengetallen. In de KLW is er voor diergewicht een beperkte differentiatie naar type koe. Dat zou bedrijfsspecifiek ingevuld moeten worden, maar borging is moeilijk. Daarvoor is extra aandacht nodig, bijvoorbeeld via een project. Wat direct door de werkgroep 'Doorontwikkelen KLW' is opgepakt is het updaten van het gemiddelde gewicht voor de categorie 'overige rassen'. Dit zal worden aangepast conform de huidige CVB-norm. De categorie 'overige rassen' gaat daarmee van $600 \mathrm{~kg}$ naar $650 \mathrm{~kg}$ en de categorie 'kruising Jersey/overige rassen' van 500 kg naar 525 kg. De categorie 'Jersey' blijft ongewijzigd.

P-gehalte melk: De beste verbetering van de KLW voor het P-gehalte in melk is bedrijfsspecifieke bepaling. Daarvoor is een methode beschikbaar (MIRS), maar die is nog niet volledig praktijkrijp. De werkgroep 'Doorontwikkelen KLW' ziet het belang van een bedrijfsspecifieke bepaling van het Pgehalte in melk en zal zich inspannen om het praktijkrijp maken van de MIRS-methodiek op de agenda te zetten.

$\mathrm{N}$ - en P-gehalte vers gras: De samenstelling van vers gras (inclusief VEM-gehalte) vertoont veel variatie gedurende het seizoen. De variatieschommelingen lijken niet constant in de tijd, zodat differentiatie van de in de KLW gebruikte N/VEM- en P/VEM-verhouding (die gerelateerd worden aan die van graskuil) niet eenvoudig is. Om een goede invulling aan een dergelijke differentiatie te kunnen geven is een projectmatige aanpak nodig.

\section{Maatschappelijke waarde}

I dentificatie maatschappelijke waarde

Voor de maatschappelijke waarden is binnen de werksessies vanuit verschillende perspectieven gekeken naar het begrip zelf. De maatschappij kan hierbij bezien worden vanuit de eigen directe (bedrijfs)relatie met de maatschappij, in sectorverband of vanuit burgerperspectief. Voor wie is welke informatie en in welke vorm van belang?

Binnen de sector is het gebruikelijk om waarden in een kengetal uit te drukken. In sectorverband richten de maatschappelijke gerelateerde waarden zich vooral op kritische prestatie-indicatoren in relatie tot milieu en biodiversiteit. Deze kengetallen zeggen veel over en voor de sector zelf. De 
kengetallen weidegang, energie (verbruik en productie) en $\mathrm{CO}_{2}$-bijdrage (carbon footprint) scoren hoog bij het profileren van het eigen bedrijf naar de omgeving. Of dit aansluit bij de behoefte en belevingswereld van de maatschappelijke omgeving wordt als vraagstuk gezien. Een indicator met maatschappelijke waarde hoort in eerste instantie voor de maatschappij te gelden. Communicatie en een transparante bedrijfsvoering wordt hierin door de deelnemers als belangrijke randvoorwaarde voorop gesteld. De maatschappij bekijkt de melkveehouderij immers niet vanuit scores of kengetallen maar reageert vanuit beleving en emotie.

Inhoudelijke uitkomsten

In de eerste inventarisatie zijn de volgende maatschappelijke waarden benoemd:

- Weidegang

- Biodiversiteit in brede zin (waaronder landschappelijke variëteit, weidevogels, effect schoon water)

- $\mathrm{CO}_{2}$ - energieneutraal

- Beperken milieuverliezen

Aan de hand van de praktijksessies is verder ingezoomd op KLW-kengetallen die gebruikt kunnen worden als maat voor de maatschappelijke waarde van het melkveebedrijf. Daarbij kwamen de volgende aandachtspunten naar voren:

- Koppeling aan technische kengetallen KLW

- Gebruik KLW

- Inhoudelijke meerwaarde

- Nieuwe vragen

- Identificatie maatschappelijke waarde

Koppeling aan technische kengetallen KLW (gegevens 2016): De KLW en de achterliggende Centrale Database KLW kan veel kengetallen laten zien. Uiteindelijk is in de werksessies nader gekeken naar de kengetallen:

- Uren weidegang

- \% Blijvend grasland van totaal areaal

- Bodemoverschot $\mathrm{N}$ in kg per ha

- \% $\mathrm{N}$ in voer (geteeld van eigen land)

- Ammoniakemissie in $\mathrm{kg}$ per ha

- Broeikasgassen in $\mathrm{CO}_{2}$ equivalenten per $\mathrm{kg}$ melk

Gebruik KLW: De deelnemers spreken zich nadrukkelijk uit tegen het gebruik van de KLW voor andere doeleinden dan eigen managementinformatie. De KLW wordt in hun beleving steeds meer een instrument dat ingezet wordt voor strategische en/of beleidsmatige sectorbelangen.

Inhoudelijke meerwaarde: De inhoudelijke meerwaarde van de in dit project benoemde 'nieuwe' technische kengetallen wordt door de deelnemers onderkend, maar deze kengetallen c.q. maatschappelijke indicatoren horen in hun beleving niet thuis bij de basisrol van de KLW. De basis van de KLW is bedrijfsspecifieke informatie over de mineralenkringlopen voor het eigen management. Extra informatie die beschikbaar kan komen uit de KLW of de achterliggende Centrale Database moet volgens de deelnemers bij voorkeur apart worden gepresenteerd.

I dentificatie maatschappelijke waarde: Er is aarzeling bij het gebruik van indicatoren voor maatschappelijke waarde, omdat er vragen zijn omtrent hoe de kengetallen worden vastgesteld, hoe ze worden gewaardeerd, door wie ze worden gebruikt en waarvoor ze worden gebruikt. Het is geen objectieve maat omdat de waarde en de waardering van de score per gebruiker (melkveehouder, directe omgeving/maatschappij, zuivelaar of de melkveesector) kan verschillen. 


\section{Inleiding}

\subsection{Achtergrond}

In het kader van de Uitvoeringsregeling Meststoffenwet wordt gewerkt met excretieforfaits voor stikstof en fosfaat voor melkvee voor het bepalen van de hoeveelheid af te voeren mest. Die excretieforfaits zijn een door het Centraal Bureau voor de Statistiek vastgesteld gemiddelde van de sector over een periode van 3 jaar. De excretieforfaits worden regelmatig aangepast aan de actualiteit. Echter, een gemiddelde als excretieforfait betekent ook dat een deel van de melkveehouders een duidelijk hogere dan wel lagere excretie heeft dan het forfait en dus respectievelijk een voordeel dan wel nadeel heeft bij het gebruik van het forfait.

Een melkveehouder die zich benadeeld voelt kan op basis van vrije bewijsleer afwijken van de excretieforfaits, maar dit is een ingewikkelde procedure. Daarom is de Nederlandse overheid in 2006 de melkveehouder tegemoet gekomen met een handreiking (https://www.rvo.nl/file/handreikingbedrijfsspecifieke-excretie-melkvee). De Handreiking is tot een praktisch instrument uitgewerkt als de rekenmodule Bedrijfsspecifieke Excretie (BEX). Met de BEX is het voor bedrijven die een nadeel hebben bij het gebruik van de excretieforfaits mogelijk om de mestafvoer te bepalen op basis van eigen bedrijfsspecifieke gegevens.

De KringloopWijzer (KLW) bouwt verder op de BEX en geeft inzicht in de mineralenkringloop van dier, voer, bodem, en mest. Op basis van bedrijfseigen data worden met de KLW kengetallen en overzichten gegenereerd waarmee een melkveehouder het bedrijfsmanagement kan analyseren en verbeteren.

Bij de ontwikkeling van de KringloopWijzer (KLW) als managementinstrument is gekeken of de KLW bruikbaar is voor (een goede afspiegeling van) de melkveesector. Bij validatie door de Commissie van Deskundigen Meststoffenwet (CDM) bleek dat de betrouwbaarheid en nauwkeurigheid van de met de KLW berekende kengetallen voor ongeveer $80 \%$ van de Nederlandse melkveebedrijven voldoende geborgd is. Inmiddels is de maatschappelijke druk op de melkveehouderijsector toegenomen om mineralen meer en meer efficiënt te gebruiken. Dat zorgt ervoor dat het managementinstrument KLW inmiddels ook gebruikt wordt als verantwoordingsinstrument. Zo heeft de zuivelsector, per 1 januari 2016, het invullen van de KLW verplicht gesteld voor alle melkveehouders. Dat geldt ook voor de ca $20 \%$ bedrijven waarvoor de juistheid van de KLW niet getoetst kan worden. Deze verplichtstelling geeft vooral extensieve ${ }^{1}$ bedrijven het gevoel dat zij niet tot hun recht komen. Ook bedrijven met een ander rastype dan Holstein-Friesian (HF) benoemen dit gevoel. Om dit gevoel te onderzoeken en indien mogelijk weg te nemen (b.v. door de KLW aan te passen) is door LTO Noord het in deze rapportage beschreven project opgezet. Naast het eventueel aanpassen van rekenregels is in dit project ook onderzocht of vanuit kengetallen van de KLW die (nog) niet op de voorgrond treden, een maatschappelijke waardevolle indicator voor deze bedrijven benoemd kan worden.

\subsection{Doel en doelgroep}

Het project kende twee doelen. Het eerste doel was om, samen met vooral extensieve melkveebedrijven en bedrijven met een veestapel die afwijkt van het type Holstein-Friesian (HF), via inhoudelijke analyse na te gaan of de KLW (on)voldoende recht doet aan hun bedrijfsspecifieke

\footnotetext{
${ }^{1}$ Extensieve melkveebedrijven zijn in het algemeen bedrijven met veel grond, doen veel aan weidegang en hebben daardoor veel (vers) gras in hun rantsoen. Daarmee hebben ze een eiwit- en fosforrijk rantsoen en kopen verhoudingsgewijs weinig voer aan. Vooral op het onderdeel vers gras in het rantsoen ontbreekt het aan goede bedrijfsspecifieke invoerwaarden voor de KLW, zodat er default invoerwaarden (=gemiddelden over bedrijven) gebruikt moeten worden. Het is mogelijk dat de defaultwaarden er mede oorzaak van zijn dat extensieve bedrijven zich niet herkennen in de KLW.
} 
omstandigheden. De bevindingen zijn beschreven en er is gezocht naar verbetering van geconstateerde tekortkomingen. De resultaten zijn aan het project KLW overgedragen met het verzoek om de KLW, zo mogelijk, aan te passen. Hiervoor zijn inhoudelijke verbetersuggesties meegegeven.

Het tweede doel was om voor de extensieve bedrijven een maatschappelijk waarde via KLWuitkomsten inzichtelijk te maken. Dat gebeurde via indicatoren die samen met de deelnemende veehouders zijn benoemd. Het was daarbij de ambitie om dat te doen op basis van de bestaande data-input van de KLW, dus zonder extra gegevens van de veehouder te vragen. 


\section{Aanpak}

De aanpak wordt beschreven in chronologie van de projectactiviteiten.

\subsection{Werving en selectie van deelnemende bedrijven}

Het project heeft gewerkt met 14 deelnemers die uit 6 provincies van boven de grote rivieren komen. Van 1 van de deelnemers bleek onvoldoende informatie beschikbaar om de voorgenomen analyse uit te voeren. De rapportage heeft daarom betrekking op de resultaten van 13 bedrijven.

De deelnemers zijn niet openbaar geworven, maar via netwerkcontacten. Er is gekozen voor deelnemers met een kritische en open houding, die bereid waren hun bedrijfsdata in te brengen en die gezamenlijk voldoende variatie in bedrijfstypes vertegenwoordigden. Een voorwaarde voor deelname was het bekend zijn met en het gebruik maken van de KLW.

\subsection{Praktijksessies met deelnemende bedrijven}

Aan de hand van groeps- en individuele sessies zijn, gezamenlijk met deskundigen van Wageningen Livestock Research en Projecten LTO Noord, de KLW en de KLW-uitkomsten inhoudelijk met de deelnemende bedrijven doorgenomen. Op aangeven van de deelnemers zijn zwakke punten en/of niet bij hun praktijk aansluitende weergaven van hun (extensieve) bedrijfsvoering binnen de KLW benoemd. Op basis daarvan zijn tijdens dezelfde praktijksessie concrete KLW parameters benoemd waar nadere aandacht aan besteed moest worden. Ook zijn door de deelnemende bedrijven voor die parameters suggesties gedaan voor inhoudelijke verbetering. Vervolgens is in overleg vastgesteld hoe de analyse en uitwerking van de te onderzoeken parameters zou worden aangepakt. De terugkoppeling vond plaats via een gevoeligheidsanalyse.

\subsection{Gevoeligheidsanalyse}

Voor de te onderzoeken parameters hebben de betrokken deskundigen een gevoeligheidsanalyse uitgevoerd. Daarbij is voor alle kengetallen die genoemd worden op het KLW tabblad 'Kengetallen' nagegaan hoe ze veranderen als gevolg van veranderingen in de te onderzoeken parameters. De resultaten van de analyse zijn weergegeven als het gemiddelde van:

- $\quad$ een dataset die representatief is voor het gemiddelde Nederlandse melkveebedrijf $(n=1068)$

- $\quad$ het gemiddelde van de deelnemende extensieve bedrijven $(n=13)$

- $\quad$ bedrijfsspecifiek voor ieder bedrijf afzonderlijk $(n=1)$

\subsection{Verbetermogelijkheden technische KLW-kengetallen}

De resultaten van de gevoeligheidsanalyse van technische kengetallen zijn plenair teruggekoppeld. Op basis daarvan is gezamenlijk vastgesteld welke van de onderzochte invoerparameters een relevante invloed hebben op de door de KLW berekende kengetallen. De bedrijfsspecifieke analyse (wat betekent een aanpassing van een parameter voor het eigen bedrijf) bleek waardevol bij het bepalen van de relevantie van verbetering van een parameter. Voor de parameters die door de groep relevant werden geacht is geïnventariseerd hoe ze te verbeteren zouden zijn. Deze verbetermogelijkheden zijn, binnen de beschikbare ruimte van het project, zo goed mogelijk uitgewerkt en teruggekoppeld aan het project KLW (i.c. de KLW werkgroep “Doorontwikkelen KLW'). 


\subsection{KLW-kengetallen voor maatschappelijke waarde}

Tijdens de praktijksessies is tevens naar indicatoren in relatie tot de KLW gezocht waarmee een maatschappelijke waarde aangegeven (liefst kwantitatief) kan worden. Daarbij is gelet op de kwaliteit en betrouwbaarheid van deze indicatoren. $\mathrm{Er}$ is ook nagedacht over eventueel nieuwe indicatoren. Voor nieuwe indicatoren is tevens gelet op de inspanning die het vraagt van de veehouder om deze indicatoren in de KLW op te nemen en/of inzichtelijk te krijgen. Voor alle mogelijke indicatoren voor 'maatschappelijke waarde' gold dat ze op dit moment niet duidelijk als resultaatweergave bij de KLWuitkomsten in beeld worden gebracht.

Deze rapportage is een weergave van de doorlopen projectactiviteiten met bijbehorende uitkomsten en resultaten. 


\section{Resultaten praktijksessies}

\subsection{Algemeen}

Het project is gestart met een inventarisatie van inhoudelijke drijfveren van de veehouders om aan dit project deel te nemen en van onderwerpen die leven bij de deelnemers in relatie tot de KLW. Vervolgens is gezamenlijk gediscussieerd over de aangedragen onderwerpen om tot een keuze voor relevante onderwerpen te komen. Tot slot is voor die onderwerpen gediscussieerd over mogelijke verbeteringen en uitwerkingen. Het onderzoeken van de mogelijkheden voor praktische toepassing van de aangedragen verbeteringen was huiswerk voor de betrokken deskundigen. Het resultaat van dat huiswerk was de input voor volgende praktijksessies.

\subsection{Inventarisatie drijfveren en onderwerpen van deelnemers}

\subsubsection{Drijfveren deelnemers}

De belangrijkste drijfveer voor deelnemers was een gevoel van onrechtvaardigheid. De bedrijven hebben geen moeite met het mogelijk afleggen van verantwoording over hun bedrijfsresultaten, mits die resultaten correct zijn weergegeven. Vanuit dit gevoel namen de 'extensieve' veehouders deel aan het project met als centrale vraag: Komt de KLW voor belangrijke kengetallen tot correcte resultaten voor van het gemiddelde afwijkende bedrijven? Uitgaande van een ontkennend antwoord was het doel het duidelijk maken van de noodzaak voor verbetering van de KLW en vervolgens concrete voorstellen voor verbetering aan te geven. De persoonlijke doelen van de veehouders bewogen zich dan ook tussen het realiseren van goede rekenregels voor de KLW enerzijds en het vertrouwen krijgen in de gebruikte rekenregels anderzijds. Daarbij realiseerde een ieder zich dat het onmogelijk is om voor ieder bedrijf exact goede kengetallen te genereren. Dat werd dan ook niet verwacht, maar de gerealiseerde afwijking moet wel acceptabel zijn. Datzelfde geldt voor het gebruik van default waarden: acceptabel mits duidelijk is dat de afwijking van voor het gemiddelde afwijkende bedrijven niet te groot is.

\subsubsection{Onderwerpen van deelnemers}

De inventarisatie van onderwerpen is voorafgaand aan de eerste plenaire bijeenkomst telefonisch en schriftelijk gedaan (e-mail), waarna aan het begin van de praktijksessies door iedere deelnemer kort is toegelicht waarom de genoemde punten voor hem belangrijk zijn. Hieronder wordt een genotuleerd overzicht gegeven van de door de deelnemers aangedragen onderwerpen en mogelijke oplossingsrichtingen.

1. Type koe.

a. Andere veeslagen dan HF hebben een gewicht dat niet in KLW gekozen kan worden namelijk een lager gewicht dan HF maar hoger dan kruislingen. Maak invoer van een bedrijfsspecifiek gewicht mogelijk. Genoemd zijn Jersey, MRIJ en de kruising HF x Jersey. Het geldt waarschijnlijk voor meer rassen.

b. Bij andere rassen en bij inkruisen wordt de efficiëntie niet goed berekend.

2. VEM-dekking en VEM-behoefte.

a. Gewicht maakt veel verschil.

b. VEM-dekking voor Jersey niet goed berekend (Combi met P-melk: Op papier meer $\mathrm{P}$ in mest dan er daadwerkelijk aanwezig is).

c. Rantsoensamenstelling heeft invloed op de VEM-dekking / VEM-behoefte. Vragen bij de VEM-behoefte-berekening en rekenen met een vaste VEM-dekking.

d. Het systeem lijkt gebaseerd op melk produceren uit VEM, maar melk wordt niet alleen op VEM geproduceerd. 
3. Voederwaarde vers gras.

a. De default VEM-waarde gras is voor sommige bedrijven te laag (in kuilen is de VEMwaarde al hoger).

b. Biologisch melkveebedrijf: VEM in vers gras wordt niet gehaald omdat er weinig bemest wordt. Hierdoor wordt op dat gras minder melk geproduceerd dan wordt ingerekend door de KLW.

c. De voederwaarde zoals opgegeven door bedrijfslaboratoria wordt niet gehaald. Ook niet in de kuilen. De gemiddelde extensieve boer heeft hetzelfde probleem, er wordt ander gras geproduceerd dan het default ingerekende gras.

4. $\mathrm{N}$ - en $\mathrm{P}$-gehalte vers gras.

Het schatten van de gehaltes in vers gras op basis van de kuilsamenstelling is niet goed. Dat is vooral belangrijk voor extensieve bedrijven omdat vers gras daar makkelijk $35 \%$ van het ruwvoer kan zijn. Dat kan beter door:

a. Rekening te houden met de bijvoeding.

b. De grashoogte bij inscharen mee te nemen bv inscharen bij een maaisnede.

c. Het seizoen mee te nemen bv veel weiden op najaarsgras geeft hoge gehalten en dat levert in de KLW onherkenbare gehalten op in vers gras.

d. Voor de weideperiode (bv van 1 april - 1 oktober) extra info op te vragen om daarmee een aparte 'Beweidingskringloop' op te stellen.

e. Per perceel aan te geven of er wel/niet geweid wordt.

$\mathrm{f}$. Een relatie te leggen tussen P-gehalte bodem en P-gehalte gras.

5. Invoer voor zomerstalvoeding is te beperkt, meer mogelijkheden gewenst.

6. P-melk

a. Het forfait is te laag voor Jersey.

b. P-gehalte melk standaard laten bepalen (net zoals vet, eiwit en lactose) en bedrijfsspecifiek maken

7. De streefwaarde voor de P-efficiëntie in de voeding is niet reëel voor veel extensieve bedrijven (te hoog).

8. Weidegang

a. Bij een hoog aantal uren weidegang wordt een vers grasopname berekend die de koeien niet eens op kunnen nemen.

b. Weidegang kent per koe zowel $12 \mathrm{~kg}$ droge stof per dag per koe opname maar ook $4 \mathrm{~kg}$. In de KLW komt het tweede redelijk goed uit, het eerste niet.

c. De bemestingsnorm voor weiden is anders dan voor voederwinning.

d. Beweidingsverliezen (in verschillende systemen) lijken anders ingerekend te worden dan in Europa gebruikelijk is.

9. Duurzaamheid

a. Kengetallen uitdrukken per $\mathrm{kg}$ vet en eiwit geeft een eerlijker weergave.

b. Maatschappelijk belang ... produceren van eigen voer wordt momenteel niet 'gewaardeerd'.

10. BEX en KLW geven niet hetzelfde fosfaatvoordeel.

11. Opbrengst mais wordt iets te hoog ingeschat

12. Opbrengst van gras wordt iets te laag ingeschat

13. Weiden op beheersland (bv pinken): zit dat goed in de KLW?

14. Landruilen met bv akkerbouwer: zit dat goed in de KLW?

15. Over elkaar heen kuilen van snedes: hoe gaat dat met bemonsteren c.q. wordt de oude kuil 2 keer meegeteld?

16. Hoe wordt de aanvoer van stro voor in de hokken en onder de maiskuil door KLW ingerekend?

17. Discrepantie tussen de groenvinkjes in de KLW en signalen belangenbehartigers waardoor bijvoorbeeld veel weide-uren eigenlijk wordt afgestraft.

18. PAL veranderingen zijn niet te zien in KLW.

19. Effect perceelgericht bemesten is niet zichtbaar in KLW. 


\subsection{Technische kengetallen}

\subsubsection{Overzicht resultaten}

De discussie over de ingebrachte onderwerpen resulteerde in consensus over de 3 belangrijkste aandachtspunten voor verbetering van de wijze waarop de KLW tot enkele technische kengetallen komt. Bij ieder aandachtspunt zijn door de deelnemers verschillende mogelijkheden voor verbetering aangegeven (kort weergegeven als $a, b$ en $c$ en nader toegelicht in §3.3.2):

1. Vers gras

a. Samenstelling beter vaststellen en

b. Opname beter berekenen door:

i. Bijvoeding meenemen

ii. Onderscheid naar voorjaar en najaar

iii. Onderscheid naar beweidingssysteem bv strip-grazen, standweiden, zomerstalvoeren

iv. Onderscheid naar inschaarhoogte cq snedezwaarte bij zomerstalvoeren

2. VEM-behoefte en VEM-dekking
a. VEM-behoefte op basis van onderscheid naar ras
b. VEM-behoefte bedrijfsspecifiek maken op basis van diergewicht
c. VEM-dekking bedrijfsspecifiek maken

3. P-melk

a. Default waarde differentiëren naar ras

b. Bedrijfsspecifiek maken

\subsubsection{Toelichting aangedragen mogelijkheden voor verbetering}

1. Samenstelling vers gras

a. Regelmatig monsters nemen en daarin de samenstellen bepalen is de beste manier. Dit gebeurt bijvoorbeeld wekelijks in de grasmonitor (data op website van de Weideman). Echter, dit brengt (te) veel werk en kosten voor de gemiddelde veehouder met zich mee. Kunnen de data van de grasmonitor gebruikt worden om de verhouding vast te stellen tussen samenstelling vers gras per grondsoort/regio en het kuilgras op het eigen bedrijf? Met die verhouding vervolgens bedrijfsspecifiek rekenen in plaats van de default-verhouding die nu door KLW gebruikt wordt.

b. Gebruik de data van de grasmonitor en neem ook $\mathrm{P}$ mee. Ook voor $\mathrm{P}$ de relatie met de eigen kuilen leggen (zie punt a).

c. Laat zien wat de aanpak in punt a en b doet met de resultaten van de huidige KLW (gaat het ergens over?). Niet alleen gemiddelden laten zien, maar ook/juist de spreiding tussen bedrijven.

2. Opname vers gras

a. De modellen voor de vers grasopname verbeteren.

b. Hetzelfde model als nu in de KLW gebruiken maar differentiëren door 3 of 4 varianten op te nemen.

c. Probeer $a$ en $b$ af te stemmen op de vers gras samenstelling (liefst in combi met snedezwaarte).

d. Snedezwaarte meten door bijvoorbeeld de grashoogte te meten bij in- en uitscharen.

e. 'Pasture reader' op maaibalk gebruiken.

f. Onderscheid maken naar beweidingssysteem omdat het invloed heeft op de grasopname en de vers gras verliezen.

g. In de KLW kan de bijvoeding bij weiden niet ingevoerd worden. Dat is een gemis omdat de bijvoeding invloed heeft op de vers gras opname.

h. De KLW heeft een modelberekening voor de vers gras opname. Daar is weinig vertrouwen in omdat de daarmee berekende opnames niet aansluiten bij wat in de praktijk wordt gerealiseerd. Bereken de vers gras opname op basis van een VEM-restpost. 
i. Laat zien wat de impact is bij alle varianten. Nog duidelijker maken dat goed is nagedacht en doorgerekend.

j. Aanvullende opmerkingen:

- Effect van robot-melken meenemen.

- Opbrengst in de wei zelf bepalen (in samenhang met beweidingssysteem).

- Seizoenverschillen meenemen.

- Wees realistisch, niet iedereen zal de vers grasopname dagelijks gaan bijhouden.

3. VEM-behoefte

a. Gebruik de I\&R registratie met betrekking tot de bloedvoering om het gemiddelde gewicht uit te rekenen. Opmerking: Als de bloedvoering onduidelijk is valt de KLW terug op HF. Dat gebeurt onder andere als je een niet geregistreerde Jersey stier inzet. In dat geval is het duidelijk dat de resultaten afwijken als met het default HF gewicht wordt gerekend.

b. Gebruik, indien beschikbaar, gemeten diergewicht (bv bij robotmelkers vaak aanwezig)

c. Leidt het gemiddelde gewicht af van de data 'geslacht gewicht' die bij afvoer van koeien beschikbaar komen en controleerbaar zijn. Laat het 'geslacht gewicht' via de Centrale Database KLW lopen.

4. P-gehalte melk

a. Meten=weten! Maak het mogelijk om van iedere geleverde tank melk het P-gehalte te bepalen. Wellicht is er nog een project nodig voor validatie. Gedacht wordt aan ontwikkelen methodiek op basis van I nfra Rood Spectroscopie of nieuwe sensortechnologie. De zuivelindustrie kan de melk ook controleren op weidemelk d.m.v. een indicator. Ook ieder kwartaal $\mathrm{P}$ meten in de melk geeft een indicatie voor het jaar.

b. Meer onderzoek naar oorzaak van de spreiding is nodig.

c. Indien analyse van tankmelk lastig is, kan de P-norm voor melk gedifferentieerd worden bijvoorbeeld differentiëren naar ras, lactatiestadium, productieniveau, rantsoen.

d. Werken met schattingsformules voor $P$ in melk bijvoorbeeld Klop e.a., 2014 (J ournal of Agricultural Science, 152, 860-869).

5. Opmerkingen overig

a. Om de grasopname te sturen naar meer realistische opnames wordt in de praktijk bij het invullen van de KLW het aantal weide-uren teruggebracht (dus lager aantal uren invullen dan daadwerkelijk is geweid). Vaak is 720 uur per jaar dan de uitkomst (minimum omdat anders de weidepremie vervalt).

b. Grashoogte meten is onbetrouwbaar wanneer er meer dan $2000 \mathrm{~kg}$ ds/ha staat.

c. De bedrijfslaboratoria geven te hoge voederwaarden, moeten we hier nog iets mee?

d. Wat is de rol van mestmonsters?

e. Niet vergeten; de extra te verzamelen/verkrijgen data moeten op wel borgbaar zijn

f. Speelt het gewicht van de koe alleen bij de berekening van de VEM-behoefte?

g. Rol ligging kavels (veldkavel) bij mest en grasopbrengst.

h. Aanvoer / gebruik nieuw materiaal bij oude (aangezette) kuil, gebruik stro.

i. Gebruik gras van agrarisch natuurbeheer.

j. Er is algemene huiver voor het gebruik van kengetallen uit de KLW voor maatschappelijke waarden. Wat nu vrijwillig is kan morgen verplicht zijn. En voor wie doe je het, voor jezelf, voor de omgeving, de maatschappij, de zuivelaar of de sector? De KLW is een managementinstrument.

\subsection{Maatschappelijke waarde}

\subsubsection{Overzicht resultaten}

Tijdens de praktijksessies is het onderwerp maatschappelijke waarde op verschillende manieren benaderd:

- Definitie van maatschappelijke waarde en bijbehorende indicatoren

- Koppeling aan technische kengetallen KLW

- Gebruik KLW 
- Inhoudelijke meerwaarde

- Nieuwe vragen

- Identificatie maatschappelijke waarde

Er zijn inmiddels meerdere partijen bezig met het uitlichten van indicatoren met een maatschappelijke waarde. Weidegang, energie, biodiversiteit, $\mathrm{CO}_{2}$-footprint en water zijn momenteel belegd bij diverse initiatieven.

Het blijft daarbij de vraag voor wie de informatie, in welke vorm, van belang is. Betreft het managementinformatie voor jezelf of laten zien wat je presteert of afrekenen op prestaties (in de vorm van minimumeisen of prestatiebeloning).

\subsubsection{Toelichting}

1. Definitie van maatschappelijke waarde en bijbehorende indicatoren Allereerst is stilgestaan bij de benaderingsmogelijkheden van het begrip maatschappelijke waarde. De maatschappij kan gezien worden vanuit de eigen directe (bedrijfs) relatie met de maatschappij, in relatie tot de sector of de maatschappelijke waarde gezien vanuit burgerperspectief.

Voor wie is welke informatie en in welke vorm van belang? Binnen de sector is het gebruikelijk om waarden in een kengetal uit te drukken. De maatschappelijke waarden in sectorverband richten zich vooral op kritische prestatie-indicatoren in relatie tot milieu, klimaat en biodiversiteit. Deze kengetallen zeggen echter vooral veel over en voor de sector zelf. Het sluit niet automatisch goed aan op de behoefte en belevingswereld van de maatschappij of omgeving. De maatschappij bekijkt de melkveehouderij niet vanuit scores of kengetallen maar reageert vooral vanuit beleving en emotie. Daarbij gaat het in de eerste plaats dus om goede communicatie. De omgeving wordt alleen overtuigd door het vertellen van het juiste en goede verhaal met een transparante bedrijfsvoering (kom zelf kijken). Er moet nadruk gelegd worden op het totaalplaatje waarbij voorkomen moet worden dat partijen 'aan de haal gaan' met deelstukken als dat zo in hun straatje past.

In de eerste inventarisatie zijn de volgende maatschappelijke waarden benoemd:

- Weidegang

- Biodiversiteit in brede zin (o.a. landschappelijke variëteit, weidevogels, effect schoon water)

- $\mathrm{CO}_{2}$ - energieneutraal

- $\quad$ Beperken milieuverliezen

2. Koppeling aan technische kengetallen KLW

Koppeling aan technische kengetallen KLW (gegevens 2016): De KLW en de achterliggende Centrale Database KLW kan veel kengetallen laten zien. Naar aanleiding van de verschillende sessies is uiteindelijk nader gekeken naar de kengetallen:

- Uren weidegang

- \% Blijvend grasland van totaal areaal

- Bodemoverschot $\mathrm{N}$ in $\mathrm{kg}$ per ha

- $\quad \% \mathrm{~N}$ in voer (geteeld van eigen land)

- Ammoniakemissie in $\mathrm{kg}$ per ha

- $\quad$ Broeikasgassen in $\mathrm{CO}_{2}$ eq per kg melk

Vanuit de gevoerde discussies kwam naar boven dat;

- $\quad$ Een index voor bodemgebruik mist, een getal dat aangeeft hoe een melkveehouder om gaat met alles wat met de bodem van doen heeft. Het zou een cijfer moeten zijn dat opgebouwd wordt uit waarderingen voor de bodemoverschotten $\mathrm{N}$ en $\mathrm{P}$, maar ook de opbouw van organische stof, toegediende meststoffen en gewasrotatie.

- De deelnemers zich onvoldoende kunnen identificeren met het LEI-BIN gemiddelde. In het verlengde daarvan, je eigen bedrijf naast vergelijkbare bedrijven zetten en dan zien hoe maatschappelijk gescoord wordt kan meerwaarde bieden.

- Het maakt nogal uit of een variabele wordt uitgedrukt in $\mathrm{kg}$ melk of per hectare. Hoe worden de 'nieuwe' kengetallen uitgedrukt? 
- Weidegang is maatschappelijk nog uit te leggen, een bodemoverschot stikstof niet. Moet er een energielabel voor de stal of het bedrijf komen zodat het de maatschappij wat zegt (naast het huizenlabel leggen)?

- Het de beleving is dat het aantal uren weidegang geen effect heeft op andere parameters.

- $\quad$ De spreiding tussen de extensieve bedrijven onderling meer vragen oproept over het gevoerde bedrijfsmanagement dan het verschil tussen de gemiddelden van intensieve en extensieve bedrijven.

- Het de vraag os of een negatief bodemoverschot wel goed is. Een effect zal zijn dat de bodem uitgemijnd wordt en de bodemvruchtbaarheid zal afnemen.

- Het belangrijk is om zelf te weten hoe een getal is opgebouwd. Met dat inzicht valt beter te begrijpen, en uit te leggen, waarom het op jouw bedrijf is zoals het is. Dat is of een gegeven, of een verbeterpunt.

- $\quad$ Landschapselementen zijn momenteel niet in de KLW in te voeren en dus niet in een kengetal te vatten. De maatschappij zal vermoedelijk wel geïnteresseerd zijn in de aanwezigheid van beheersgronden, kikkerpoelen, weidevogelbeheer of houtwallen.

\section{Gebruik KLW}

De deelnemers spreken zich nadrukkelijk uit tegen het gebruik van de KLW voor andere doeleinden dan eigen managementinformatie. De KLW wordt in hun beleving steeds meer een instrument dat ingezet wordt voor strategische en/of beleidsmatige sectorbelangen. De grens tussen vrijwillig managementinstrument en sturingsinstrument begint te vervagen.

Hieronder enkele gemaakte opmerkingen:

- $\quad$ een indicator met maatschappelijke waarde moet ook voor de maatschappij herkenbaar zijn.

- $\quad$ extensieve bedrijven (de $20 \%$ ) moeten zich ook goed kunnen presenteren met de KLW, net als alle andere bedrijven.

- de KLW is niet het instrument om maatschappelijke indicatoren inzichtelijk te maken.

- laat de KLW vooral het instrument voor de mineralenstromen zijn.

- de KLW is verworden tot een politiek instrument in tegenstelling tot een eigen managementinstrument

- de mogelijkheden van de Centrale DataBase zijn groot en vooral goed voor beleid en andere belanghebbenden. Dat staat los van de KLW als instrument voor kringlopen.

- $\quad$ grondgebondenheid komt niet goed terug in de KLW.

- $\quad$ de KLW is een instrument voor adviseurs geworden (te complex om in te vullen en het risico om fouten te maken wordt daar mee vermeden).

- $\quad$ er zitten inmiddels te veel toetsers en bellen aan de KLW.

\section{Inhoudelijke meerwaarde}

Met de aanvullende kennis die binnen dit project is opgedaan wordt de inhoudelijke meerwaarde van de 'nieuwe' technische kengetallen door de deelnemers onderkend. Er wordt op een nieuwe manier naar de uitkomsten van de KLW gekeken. Deze kengetallen c.q. maatschappelijke indicatoren horen daarentegen niet thuis bij de basisrol van de KLW. Extra informatie die beschikbaar kan komen uit de KLW of de achterliggende Centrale Database wordt daarom bij voorkeur apart gepresenteerd.

\section{Nieuwe vragen}

Hoe om te gaan met de nieuwe kengetallen? Hoe worden de nieuwe kengetallen uitgedrukt? Welke waarden moeten er aan gehangen worden en wat zegt het? Waar het ene bedrijf goed scoort op kengetal 1, scoort het andere bedrijf goed op kengetal 2. Het kunnen beide goede uitkomsten zijn, wie of wat bepaalt de score en wat betekent dat voor de eigen bedrijfsvoering?

6. Identificatie maatschappelijke waarde

Er is aarzeling bij het gebruik van indicatoren met een maatschappelijke waarde. Voor wie wordt de indicator zichtbaar en wie hecht er welke waarde aan? Is het een indicator voor jezelf als melkveehouder, voor de directe omgeving of maatschappij, de zuivelaar of de mekveesector? Wat zegt de waarde van de indicator? Wat nu als een goede score wordt gezien kan morgen achterhaald zijn of door de actualiteit een gekleurde lading krijgen. 


\subsection{Samenvatting resultaat praktijksessies}

1. Technische aspecten KLW

Er zijn 3 aspecten onderscheiden:

1. Vers gras: samenstelling (gehalte VEM, $\mathrm{N}$ en $\mathrm{P}$ ) en opname

2. VEM opname: VEM-behoefte (ras/gewicht en tussenkalftijd) en VEM-dekking

3. P-melk

Deze 3 aspecten gaven 8 punten waarvoor de gevoeligheid van de KLW moest worden vastgesteld. Het betreft het VEM- (1), N- (2) en P-gehalte (3) van vers gras, de berekende vers grasopname (4), het P-gehalte van melk (5), het gehanteerde VEM-dekkings\% (6) en de impact van gewicht (7) en TKT (8) op de berekende VEM-behoefte (Zie hoofdstuk 4. Gevoeligheidsanalyse).

2. Maatschappelijke waarde Maatschappelijke waarde hoort herkenbaar te zijn voor de maatschappij. Vanuit de KLW zijn kengetallen te benoemen die aansluiten bij sectorale kengetallen die een effect hebben op maatschappelijk gewenste effecten. De KLW is een bedrijfseigen managementinstrument met focus bij het sluiten van mineralenkringlopen.

Er zijn 4 thema's benoemd om de maatschappelijke waarde inzichtelijk te maken:

- Weidegang

- $\quad$ Biodiversiteit in brede zin (o.a. landschappelijke variëteit, weidevogels, effect schoon water)

- $\mathrm{CO}_{2}$ - energieneutraal

- $\quad$ Beperking milieuverliezen

Een transparante bedrijfsvoering en goede communicatie zijn hierbij van belang. Vanuit de Centrale Database KLW kunnen bovengenoemde thema's grotendeels inzichtelijk gemaakt worden. 


\section{Gevoeligheidsanalyse}

\section{1 Algemeen}

De gevoeligheidsanalyse is uitgevoerd om antwoord te zoeken op twee vragen:

1. Hoe gevoelig is het individuele bedrijf voor variatie in de benoemde parameters?

2. Hoe gevoelig is het gemiddelde van een groep bedrijven voor variatie in de benoemde parameters?

De reden voor dit onderscheid ligt vooral in de achtergrond van de deelnemende bedrijven cq het project. Het gaat immers om bedrijven die aangeven op één of meer aspecten van de bedrijfsvoering zodanig af te wijken van het gemiddelde Nederlandse bedrijf dat de berekeningen van de KLW niet langer recht doen aan de bedrijfsspecifieke situatie. Het gaat daarmee feitelijk om de vraag om aan te tonen dat een KLW die goede resultaten geeft voor het gemiddelde bedrijf, toch foutieve resultaten kan geven voor (onderdelen van) een individueel bedrijf.

\subsection{Werkwijze}

In de eerste praktijksessie zijn concrete parameters benoemd die via een gevoeligheidsanalyse onderzocht moesten worden. Die parameters zijn afgeleid van de genoemde aandachtspunten in paragraaf 3.4 'Samenvatting technische aspecten KLW'. In tabel 4.1 wordt een overzicht van de resultaten gegeven.

Tabel 4.1 Benoemde technische aandachtspunten KLW (§3.4) uitgewerkt tot concrete parameters voor de gevoeligheidsanalyse, inclusief de ingestelde waarde in KLW en de door de deelnemers relevant geachte variatie voor de analyse.

\begin{tabular}{|c|c|c|c|c|}
\hline Aandachtspunt & Nummer & Parameter & KLW waarde & $\begin{array}{l}\text { Relevante } \\
\text { variatie }\end{array}$ \\
\hline \multirow[t]{4}{*}{ Vers gras } & 1 & VEM-gehalte als default & 960 VEM & $+/-10 \%$ \\
\hline & 2 & $\begin{array}{l}\text { N/VEM verhouding } \\
\text { weidegras }\end{array}$ & $1,10^{2)}$ & $+/-10 \%$ \\
\hline & 3 & $\begin{array}{l}\text { P/VEM verhouding } \\
\text { weidegras }\end{array}$ & $1,05^{2)}$ & $+/-10 \%$ \\
\hline & 4 & Grasopname KLW-formule & $\mathrm{Zie}^{1)}$ & $+/-10 \%$ \\
\hline Melksamenstelling & 5 & P-gehalte melk & $\begin{array}{l}0,97 \mathrm{~g} \mathrm{P} / \mathrm{kg} \\
\text { melk }\end{array}$ & $+/-10 \%$ \\
\hline \multirow[t]{3}{*}{ VEM-behoefte } & 6 & VEM-dekking & $102 \%$ & $+/-5 \%$ absoluut \\
\hline & 7 & Diergewicht & $\begin{array}{l}400 / 500 / 600 \\
\mathrm{~kg}\end{array}$ & $+/-10 \%$ \\
\hline & 8 & Tussen-Kalf-Tijd (TKT) & 411 dagen & $\begin{array}{l}+50 \text { en - } 25 \\
\text { dagen }\end{array}$ \\
\hline
\end{tabular}

1) Opname weidegras $(\mathrm{kg}$ ds per dier per dag $)=(2+0,75 \times($ aantal weide-uren per dag -2$)) \times(1+$ (meetmelkproductie - 9.500) / $500 \times 0,02)$ )

2) De KLW waarde betreft de factor waarmee de N/VEM respectievelijk P/VEM verhouding van de op het bedrijf aanwezige graskuil wordt omgezet naar de N/VEM resp. P/VEM verhouding van het weidegras.

De in tabel 4.1 aangegeven variatie voor de 8 parameters is gebruikt om bestaande KLW's van bedrijven opnieuw door te rekenen. Het verschil tussen de nieuwe berekening en de standaard 
berekening van de KLW is afgemeten aan de kengetallen op het tabblad 'Kengetallen' van de KLW. Voor ieder kengetal is per parameter het effect van de relevant geachte variatie weergegeven, zodat inzichtelijk wordt hoe gevoelig de KLW is voor veranderingen in de betreffende parameter.

Bovenstaande werkwijze is gevolgd voor de deelnemende bedrijven, waarmee de vraag naar een gevoeligheidsanalyse voor het individuele bedrijf is ingevuld. Door met de bedrijfseigen KLW te werken kon de relevantie van het aanpassen van de berekening van de onderzochte parameters goed door de deelnemers worden beoordeeld, omdat het ging om de impact voor het eigen bedrijf.

Om de vraag naar de gevoeligheid van een gemiddelde van een groep bedrijven in te vullen is gewerkt met twee groepen bedrijven. De ene groep was het gemiddelde Nederlandse bedrijf (daarvoor is het gemiddelde genomen van een voor Nederland representatieve dataset van bijna 1100 bedrijven) en de andere groep was het gemiddelde 'extensieve' bedrijf (daarvoor is het gemiddelde genomen van 13 van de 14 deelnemende bedrijven - van één bedrijf was geen KLW 2015 beschikbaar-). Door de resultaten van deze twee groepen te vergelijken met het individuele bedrijf is inzicht verkregen in de vraag of een voor het eigen bedrijf relevant geachte gevoeligheid uitsluitend bedrijfsspecifiek is, specifiek voor 'extensieve' bedrijven of meer algemeen geldend.

\subsection{Resultaten}

\subsubsection{Analyse voor het gemiddelde Nederlandse bedrijf}

In Bijlage 1 is het resultaat van de gevoeligheidsanalyse voor het gemiddelde NL melkveebedrijf weergegeven. De relevante verschillen zijn gemarkeerd. Uit de bijlage blijkt dat de ingestelde $10 \%$ verandering in de parameters voor vers gras (VEM-gehalte, N/VEM en P/VEM verhouding, berekende opname) en de parameter tussen-kalf-tijd (TKT) geen relevante verschillen in de berekende kengetallen geven. Omdat de ingestelde variatie tevens de maximaal te verwachten variatie is, kan hieruit geconcludeerd worden dat de KLW voor het gemiddelde melkveebedrijf tot een goede weergave van deze kengetallen komt.

Voor de parameter P-gehalte melk blijkt dat de ingestelde variatie van 10\% tot ongeveer 3-5\% afwijking leidt in de fosfaatkengetallen (m.u.v. de kengetallen vastlegging in gewassen).

Voor de parameter VEM-dekking blijkt dat de ingestelde variatie tot ongeveer dezelfde afwijking leidt in de kengetallen voor de dierprestatie en de gewasopbrengst. Dit mag ook verwacht worden omdat de KLW begint met het berekenen van de voeropname en de genoemde kengetallen zijn daar alle van afgeleid. Een goede berekening van de VEM-behoefte en de VEM-opname (=voeropname en voederwaardebepaling) is daarom essentieel voor de KLW.

\subsubsection{Analyse voor het gemiddelde 'extensieve' bedrijf}

In Bijlage 2 is het resultaat van de gevoeligheidsanalyse voor het gemiddelde 'extensieve' melkveebedrijf weergegeven. De relevante verschillen zijn gemarkeerd. Uit de bijlage blijkt dat de gevoeligheid voor de onderzochte parameters voor het gemiddelde extensieve melkveebedrijf grotendeels overeenkomen met die van het gemiddelde NL melkveebedrijf. De opmerkingen van §4.3.1 kunnen hier alle herhaald worden. Bovendien moet daar aan toegevoegd worden dat de 'extensieve' bedrijven gevoeliger zijn voor de parameter N/VEM verhouding vers gras t.o.v. N/VEMverhouding aangelegde graskuil. Dat blijkt uit de resultaten voor de kengetallen BEX ( N-excretie), Nopbrengst grasland en de ammoniakemissie.

\subsubsection{Analyse voor het individuele bedrijf}

\subsubsection{Over-all analyse}

In Bijlage 3 is het resultaat van de gevoeligheidsanalyse voor elk individueel bedrijf weergegeven. De weergave is echter aangepast ten opzichte van bijlage 1 en 2 . Het aantal kengetallen is beperkt tot wat de deelnemende melkveehouders als belangrijke kengetallen ervaren. Daarmee wordt de gegeven informatie overzichtelijker. Ook zijn in deze bijlage de resultaten direct uit de KLW overgenomen (dus 
niet relatief uitgedrukt), zodat ze vergeleken kunnen worden met de resultaten van de reguliere KLW. Dat geeft meer houvast bij het beoordelen van de relevantie van het verschil.

Ook in deze bijlage zijn de relevante verschillen gemarkeerd, maar nu met de kleuren geel en roze. Geel staat voor verschillen waarvan de veehouder vindt dat ze onacceptabel zijn c.q. dat daarmee het eigen bedrijf geen recht wordt gedaan. Die parameters moeten worden aangepast voordat de KLW als mogelijk verantwoordingsinstrument geaccepteerd wordt. Dat geldt voor iedere parameter waar minimaal 1 keer geel op is gescoord. Immers, het gaat voor extensieve bedrijven om de juistheid waarmee de KLW kengetallen berekent voor het individuele bedrijf. Roze staat voor verschillen die wel relevant worden gevonden, maar geen (groot) struikelblok zijn bij de acceptatie van de KLW als verantwoordingsinstrument. In tabel 4.2 worden de resultaten van Bijlage 3 weergegeven.

Tabel 4.2 Resultaten gevoeligheidsanalyse voor individuele 'extensieve' bedrijven. Parameters gerangschikt naar aantal keren 'geel' (= belangrijk om parameter anders te bepalen dan in de standaard KLW van 2017). De indicatie 'roze' geeft aan dat er een relevant verschil is, maar niet groot genoeg om de KLW als verantwoordingsinstrument af te wijzen.

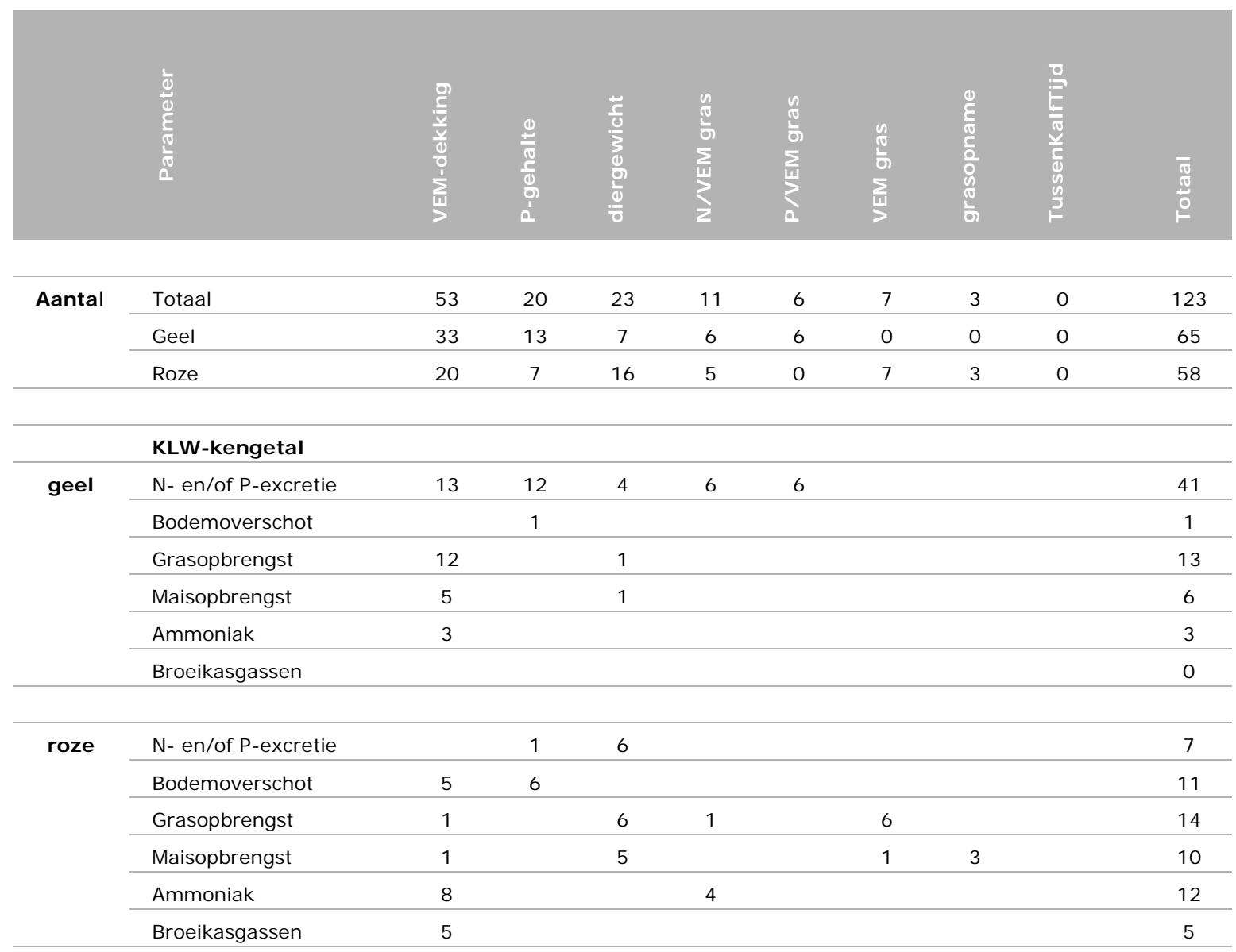

Uit bijlage 3 en tabel 4.2 blijkt dat de eerste 5 parameters (VEM-dekking, P-gehalte melk, diergewicht, $\mathrm{N}$ - en P-gehalte vers gras) geel gescoord hebben. Dat betekent dat het voor deze parameters voor de deelnemende ondernemers noodzakelijk is dat de berekening en/of vaststelling wordt verbeterd.

\subsubsection{Detail analyse}

Naast de overall analyse op basis van bijlage 3 is ook een detail analyse gedaan. Daarbij is tevens een inschatting gemaakt of relevante verschillen te verbinden zijn aan het bedrijfstype.

De VEM-dekking heeft impact op:

- de BEX-excretie resultaten van alle bedrijven. Dit lijkt niet gebonden aan bedrijfstype.

- de grasopbrengst van alle bedrijven, waarvan 12 keer geel. Dit lijkt niet gebonden aan bedrijfstype. 
- de maisopbrengst van alle 6 bedrijven die mais verbouwen, waarvan 5 keer geel. Dit lijkt niet gebonden aan bedrijfstype.

- $\quad$ de NH3-emissie van 11 van de 13 bedrijven, waarvan 3 keer geel. Dit lijkt niet gebonden aan bedrijfstype.

- $\quad$ het $\mathrm{N}$-bodemoverschot van 5 bedrijven, waarvan geen enkele geel. Dit lijkt niet gebonden aan de beweidingsintensiteit.

- de Broeikasgassen (BKG) van 5 bedrijven, waarvan geen enkele geel. Dit lijkt niet gebonden aan de beweidingsintensiteit.

Het P-gehalte van de melk heeft impact op:

- de BEX-excretie resultaten van alle bedrijven, waarvan 12 keer geel. Grootte tussen 3-5\% (gem 6,7 var 4,3 tot 8,0 kg P205/ton melk). Dit lijkt niet gebonden aan bedrijfstype.

- $\quad$ het P-bodemoverschot van 7 bedrijven, waarvan 1 keer geel. Grootte tussen 2-5\% (-28 tot +19 kg P2O5/ha). Dit lijkt niet gebonden aan de beweidingsintensiteit.

Het diergewicht heeft impact op:

- de BEX-excretie resultaten van 10 bedrijven, waarvan 4 keer geel. Dit lijkt niet gebonden aan bedrijfstype.

- Op de grasopbrengst van 7 bedrijven, waarvan 1 keer geel. Hiervan kan niet vastgesteld worden of dit wel of niet gebonden is aan het bedrijfstype.

- $\quad$ Op de maisopbrengst van alle 6 bedrijven die mais verbouwen, waarvan 1 keer geel. Hiervan kan niet vastgesteld worden of dit wel of niet gebonden is aan het bedrijfstype.

De samenstelling van vers gras uitgedrukt als N/VEM heeft impact op:

- de BEX-excretie resultaten van 6 bedrijven, waarvan 6 keer geel. Dit lijkt gebonden aan de beweidingsintensiteit.

- de NH3- emissie van 4 bedrijven, waarvan geen enkele geel. Hiervan kan niet vastgesteld worden of dit wel of niet gebonden is aan het bedrijfstype.

- de grasopbrengst van 1 bedrijf, niet geel. Hiervan kan niet vastgesteld worden of dit wel of niet gebonden is aan het bedrijfstype.

De samenstelling van vers gras uitgedrukt als P/VEM heeft impact op:

- de BEX-excretie resultaten van 6 bedrijven, waarvan 6 geel. Dit lijkt gebonden aan de beweidingsintensiteit.

Het VEM-gehalte van vers gras heeft impact op:

- de grasopbrengst van 6 grasbedrijven (200-600 kg ds /ha), waarvan geen enkele geel. Hiervan kan niet vastgesteld worden of dit wel of niet gebonden is aan het bedrijfstype.

De Tussen-Kalf-Tijd heeft geen impact op de KLW-kengetallen

\subsection{Samenvatting gevoeligheidsanalyse}

Uit de gevoeligheidsanalyse blijkt dat de Kringloopwijzer tot een afwijkend resultaat voor de KLWkengetallen kan komen voor een bedrijf dat voor (één van) de onderzochte 5 parameters afwijkt van het gemiddelde Nederlandse bedrijf. Het betreft vooral de kengetallen van de BEX en de berekende grasopbrengst. Ook het bodemoverschot, de maisopbrengst en de ammoniakemissie laten verschillen zien.

Het aantal kengetallen dat afwijkt en de grootte van de afwijking verschilt per bedrijf. Daarbij is voor de deelnemende bedrijven in dit project geen duidelijke relatie gezien met bedrijfstype of beweidingsintensiteit, met uitzondering van het geschatte $\mathrm{N}$ - en P-gehalte van vers gras (mogelijke relatie met beweidingsintensiteit). Afwijkende kengetallen kunnen verwacht worden voor bedrijven met veel vers gras in het rantsoen en of gras met een van het Nederlandse gemiddelde afwijkende samenstelling. Daarnaast kunnen afwijkingen verwacht worden voor bedrijven met een ander type vee dan HF met name als gevolg van een afwijkend diergewicht (van de keuzemogelijkheden in de KLW) of een ander P-gehalte in de melk (dan in de KLW als standaard wordt gebruikt). 
Er zijn 8 parameters benoemd waarvan verwacht werd dat ze een grote invloed hebben op de berekening van de betreffende kengetallen. Voor 5 van die parameters bleek de verwachting juist te zijn. Het betreft de VEM-dekking, het P-gehalte van melk, het diergewicht en het $\mathrm{N}$ - en P-gehalte van vers gras (N/VEM gras en P/VEM gras). Via aanpassing van de vaststelling en/of berekening van deze 5 parameters kan de KLW verbeterd worden voor 'extensieve' bedrijven.

Voor de overige 3 parameters bleek dat ze geen relevante invloed hebben op door de KLW berekende kengetallen. Echter, voor ongeveer de helft (7) van de deelnemende bedrijven bleek dat het VEMgehalte van gras wel verschillen kan geven, maar niet groot genoeg om de KLW als verantwoordingsinstrument af te wijzen. De invloed van de parameters 'vers gras opname' en 'Tussen-Kalf-Tijd' bleek voor geen enkele van de bedrijven groot te zijn. 


\section{Mogelijkheden tot verbetering KLW}

\subsection{Algemeen}

Uit hoofdstuk 4 blijkt dat het belangrijk is om de vaststelling/berekening van 5 parameters te verbeteren. Het betreft de VEM-dekking, het P-gehalte van melk, het diergewicht en het $\mathrm{N}$ - en Pgehalte van vers gras (N/VEM gras en P/VEM gras). Omdat de parameter VEM-dekking sterk bepaald wordt door de berekende VEM-behoefte is voor verbetering van de KLW gezocht naar mogelijkheden om de vaststelling/berekening van de volgende 5 parameters aan te passen:

- VEM-behoefte

- Diergewicht

- P-gehalte melk

- $\quad$ N-gehalte vers gras

- P-gehalte vers gras

\subsection{VEM-behoefte}

In de KLW gebeurt de berekening van de VEM-behoefte volgens de huidige CVB richtlijnen voor de HF koe. Die richtlijnen zijn opgesteld in 1975 door van Es (Feed evaluation for dairy cows. Livestock Production Science 2(2): 95-107) en zijn daarmee gebaseerd op onderzoeksgegevens van vóór 1970. De melkkoe van vóór 1970 en de huidige melkkoe verschillen enorm van elkaar in melkproductie, lichaamssamenstelling en gewicht. Uit recent onderzoek komt naar voren dat de onderhoudsbehoefte van de moderne melktypische koe ongeveer $30 \%$ hoger is dan de huidige CVB-norm. Ook de efficiëntie waarmee energie wordt omgezet in melk is sinds 1975 gestegen. Verder lijkt de VEMbehoefte (en daarmee de rekenregels voor VEM-behoefte) gerelateerd te zijn aan het type koe en is onderzoek nodig om vast te stellen of de VEM-behoefteberekening voor de melktypische koe zonder aanpassing gebruikt kan worden voor het vleestype en dubbeldoel type.

Op basis van bovenstaande is in de PPS DZK besloten om in 2018 te starten met onderzoek om de VEM-behoefte te updaten voor de HF koe, waarmee ruim $90 \%$ van de Nederlandse veestapel wordt afgedekt. Het betreft een melktypische koe, waarmee in principe alle melktypische rassen (zoals HF en Jersey) en kruislingen tussen melktypische rassen bediend worden, mits verschillen in diergewicht worden meegenomen (zie § 5.3). Er bestaat interesse om te onderzoeken of andere rassen een aangepaste VEM-behoefte berekening nodig hebben, maar tot concrete voorstellen is het nog niet gekomen. Het gaat om de rassen MRIJ, Fleckvieh, Montbeliarde en de in Nederland voorkomende zeldzame rassen (minder dan 6.000 volwassen vrouwelijke dieren geregistreerd) nl Brandrood rund, Groninger Blaarkop, Fries Hollands, Roodbont Friesvee, Lakenvelder en Witrik + kleurslagen.

De mogelijkheden voor verbetering van de VEM-behoefte berekening voor HF zijn al in een project belegd. De mogelijkheden voor verbetering voor de dubbeldoelrassen zijn wel geïdentificeerd maar nog niet belegd in onderzoek.

\subsection{Diergewicht}

Het diergewicht is een belangrijke invoerparameter bij het berekenen van de VEM-behoefte en heeft daarmee direct invloed op de door de KLW berekende voeropname, $\mathrm{N}$ - en P-excretie, de productie van de zelfgeteelde gewassen en de dier- en bodemefficiëntie voor N- en P. Vanuit de 'extensieve' bedrijven wordt dan ook gepleit voor de mogelijkheid om het diergewicht in de KLW zo veel mogelijk bedrijfsspecifiek te maken. Het borgingsvraagstuk is daarbij waarschijnlijk de beperkende factor. Een ruw idee voor borging is het leggen van een relatie tussen het geregistreerde 'geslacht gewicht' van afgevoerde dieren en het 'levend gewicht' van dieren in de veestapel. Een andere mogelijkheid is 
verdere differentiatie van het diergewicht van de nu gebruikte klassen Jersey (400 kg), overige rassen $(600 \mathrm{~kg}$ ) en kruislingen Jersey $x$ overig $(500 \mathrm{~kg})$. De verdere differentiatie kan wellicht op basis van de geregistreerde bloedvoering van de veestapel waarmee dan meer dan 3 klassen gemaakt kunnen worden en een grotere diversiteit in diergewichten. Voor het uitwerken van beide genoemde opties is een vervolgproject nodig.

Vanuit de werkgroep 'Doorontwikkelen Kringloopwijzer' wordt gewerkt aan een update van het diergewicht van de HF-populatie. Die update is conform CVB-richtlijn dwz 650 kg in plaats van $600 \mathrm{~kg}$. Indien deze update wordt doorgevoerd wordt ook het gewicht van de kruisling Jersey $x$ overige aangepast van $500 \mathrm{~kg}$ naar $525 \mathrm{~kg}$.

\subsection{P-gehalte melk}

\subsubsection{Algemeen}

De KLW werkt voor alle rassen met een standaard P-gehalte in melk van 0,97 g P/kg, hoewel die waarde is vastgesteld voor de HF koe (G. Brandsma en M. Blok, 2005. Fosforgehalte in koemelk. CVB documentatierapport nr. 32, Centraal Veevoederbureau). Het P-gehalte in melk lijkt niet veel te variëren in de tijd, omdat het door de KLW gebruikte standaard P-gehalte in melk overeenkomt met het in 1975 door J. Cerbulis en H. Farrell gerapporteerde P-gehalte in HF melk (Composition of the Milks of Dairy Cattle. II. Ash, Calcium, Magnesium, and Phosphorus. Journal of Dairy Science Vol. 59, No. 4). Het onderzoek van Cerbulis en Farrell wordt hier aangehaald omdat het niet alleen inzicht geeft in de variatie in P-gehalte van de melk binnen een ras, maar ook tussen rassen (tabel 5.1).

Tabel 5.1 P-gehalte in melk als gemiddelde van individuele dieren plus standaardafwijking (Sd) voor 5 rassen melkvee (Cerbulis en Farrell, 1975).

\begin{tabular}{lcccccc} 
Ras & HF & Jersey & Guernsey & Ayrshire & $\begin{array}{c}\text { Brown } \\
\text { Swiss }\end{array}$ & $\begin{array}{c}\text { Milking } \\
\text { shorthorn }\end{array}$ \\
Gemiddeld & 0,985 & 1,330 & 1,160 & 1,010 & 1,240 & 1,090 \\
\hline Sd & 0,20 & 0,17 & 0,11 & 0,10 & 0,16 & 0,16 \\
\hline $\mathrm{N}$ & 26 & 25 & 24 & 25 & 33 & 18 \\
\hline
\end{tabular}

Uit tabel 5.1 blijkt dat het P-gehalte in melk niet alleen sterk kan variëren tussen rassen (Jersey ca $30 \%$ hoger dan HF) maar ook binnen een ras. Van de populatie van een ras bevindt zich $95 \%$ in de range van het gemiddelde $+/-2 \times \mathrm{Sd}$. Voor HF geeft dat een range voor het P-gehalte van 0,58 tot $1,38 \mathrm{~g} / \mathrm{kg}$ melk en voor Jersey een range van 0,99 tot 1,77 g P/ kg melk. Het is daarom aan te bevelen om in de KLW het P-gehalte in melk niet als standaard in te rekenen, maar te baseren op een geanalyseerd P-gehalte. De reden dat toch met een gemiddelde wordt gewerkt is dat de analyse van $\mathrm{P}$ in melk niet routinematig beschikbaar is.

Er wordt momenteel gewerkt aan het praktisch toepasbaar maken van infraroodmeting (MIRS) om het $\mathrm{P}$-gehalte in melk te bepalen. Het operationeel hebben van die techniek zou een grote stap voorwaarts zijn, omdat $\mathrm{P}$ dan meegenomen kan worden bij de reguliere bepaling van de samenstelling van de melk op een bedrijf (iedere tank melk en bij de melkcontrole). Het is dan mogelijk om in de KLW met een goed onderbouwd bedrijfsspecifiek P-gehalte in melk te werken. Vanuit de KLW-werkgroep 'Doorontwikkelen KLW' is dan ook veel interesse in dat ontwikkeltraject en wordt geprobeerd daar positief aan bij te dragen.

\subsubsection{P-melk op basis van de actuele melksamenstelling}

Naast het werken met een gemiddeld P-gehalte kan ook gekozen worden voor het schatten van het Pgehalte in de melk uit de melksamenstelling (vet, eiwit en lactose). Dat kan sinds 2014 met behulp van een regressieformule van Klop e.a. (G. Klop, J. L. Ellis, M. Blok, G. Brandsma, A. Bannink en J. Dijkstra, 2014 .J ournal of Agricultural Science (2014), 152, 860-869): 
Deze benadering heeft een gemiddelde voorspelfout van $6,2 \%$ en verklaart $61 \%$ van de geobserveerde variatie. Op basis van de verklaarde variatie concludeerden de onderzoekers dat er nog andere (melk)factoren zijn die het P-gehalte van de melk beïnvloeden. De $\mathrm{P}$ in melk bevindt zich voor ca. $70 \%$ in anorganische melkcomponenten, ca. $20 \%$ in melkeiwit (m.n. caseïne) en ca. $10 \%$ in melkvet. De onderzoekers concludeerden dat de formule gebruikt kan worden om een het gemiddelde P-gehalte in melk voor een populatie te bepalen. Daarbij moet rekening gehouden worden met seizoenvariaties in de melksamenstelling.

Gebruik voor individuele bedrijven wordt door Klop e.a. niet genoemd, maar gezien de grote restvariatie lijkt deze toepassing moeilijk te borgen.

\subsubsection{P-melk per ras}

Op basis van tabel 5.1 blijkt dat het P-gehalte tussen rassen flink kan variëren. De data zijn echter oud en niet van Nederlandse dieren. Het is daarom nodig om het P-gehalte van de verschillende rassen in Nederland te onderzoeken. Het ministerie van economische zaken (EZ) heeft opdracht gegeven om het P-gehalte van de gemiddelde Nederlandse melk gedurende 1 jaar te monitoren en het gemiddelde en de spreiding te rapporteren. Daarmee wordt duidelijk of de nu gebruikte 0,97 $\mathrm{g} \mathrm{P}$ per $\mathrm{kg}$ melk nog actueel is. Echter, de gemiddelde Nederlandse melk betreft feitelijk de HF populatie. Daarom overweegt EZ om ook voor andere rassen onderzoek naar het P-gehalte in melk te laten uitvoeren, waarbij als eerste aan melk van Jersey koeien wordt gedacht.

Afgezien van monitoring van het P-gehalte in de melk van een populatie (ras) kan het gemiddelde Pgehalte in melk voor een groep ook worden geschat op basis van een regressieformule (zie §5.4.2). Daarmee kan in principe een naar ras gedifferentieerd P-gehalte in melk worden afgeleid. Daarvoor is een set monsters nodig om de schatting te maken. Voor het ras Jersey is dat op korte termijn uitvoerbaar, omdat voor die populatie al langer de melksamenstelling wordt geanalyseerd. Op basis van de beschikbare jaarrond metingen van melkeiwit, melkvet en melksuiker is de seizoenvariatie bekend. Er is alleen aanvullende informatie nodig waarmee de relatie tussen het P-gehalte en de reguliere melksamenstelling kan worden gelegd, zodat gecontroleerd kan worden of de formule van Klop gebruikt kan worden voor het ras Jersey.

\subsection{Samenstelling vers gras}

De KLW werkt met een jaargemiddelde voor de samenstelling van vers gras en leidt deze voor een melkveebedrijf af van de samenstelling van de aangelegde graskuilen. Deze aanpak geeft bevredigende resultaten voor het gemiddelde Nederlandse melkvee bedrijf, maar de aan het project deelnemende bedrijven zijn ervan overtuigd dat deze aanpak voor bedrijven met meer dan gemiddeld aandeel vers gras in het rantsoen kan leiden tot een (te grote) overschatting van het eiwitgehalte van vers gras en daardoor van de berekende waarde van enkele KLW-kengetallen. Het goed inschatten van de jaargemiddelde bedrijfsspecifieke samenstelling van vers gras (weidegras dan wel zomerstalvoedering) is lastig, omdat daarvoor op een melkveebedrijf geen goede gegevens beschikbaar zijn. De reden is dat de samenstelling van vers gras zeer veel variatie kent (afhankelijk van seizoen, weer, grasbestand, snedezwaarte, perceel etc.) en daarom niet met enkele monsters is vast te leggen. Het alternatief, jaarrond bemonsteren en analyseren van ieder perceel vers gras, is qua arbeid en kosten niet uitvoerbaar voor praktijkbedrijven.

In het project zijn verschillende suggesties gedaan om tot een alternatief te komen (§3.3). Omdat de beschikbare ruimte in het project beperkt was, heeft de projectgroep voor nadere uitwerking gekozen voor de ogenschijnlijk best uitvoerbare optie. Het betreft de mogelijkheid om de standaardwaarden voor de verhouding tussen N/VEM in kuilgras en vers gras te vervangen door een regio- of grondsoort gebonden verhouding. Daarvoor zijn gegevens over vers gras in verschillende regio's nodig, bij voorkeur van gemiddelde bedrijven en 'extensieve' bedrijven. Helaas zijn die gegevens niet beschikbaar, maar voor gemiddelde bedrijven zijn gegevens van het VEM- en eiwitgehalte van vers gras te vinden op de website van de Weideman (http://veeteelt. nl/voeding/content/versgrasupdate- 
seizoen-sluit-stijl-af). De Weideman publiceert gedurende het grasseizoen wekelijks de samenstelling van vers gras voor 7 regio's in Nederland en baseert zich op gegevens van ABZ Diervoeding, CAV Den Ham, De Heus (www.kijkopgras.nl), De Samenwerking (Weidewijzer), Schothorst Feed Research, ForFarmers (VersGrasMonitor), AgruniekRijnvallei, Voergroep Zuid, Eurofins Agro, Grip op Gras, Amazing Grazing en Precisielandbouw 2.0.

De vers gras samenstelling op basis van de informatie op de website van de Weideman blijkt inderdaad niet representatief te zijn voor de deelnemende bedrijven. Het per regio berekende jaargemiddelde eiwitgehalte van vers gras op basis van de Weideman lag in een andere range dan het door de KLW berekende eiwitgehalte in vers gras voor de deelnemende bedrijven in die regio. Het gemiddelde eiwitgehalte op basis van de Weideman was in zowel 2015 als 2016 voor klei ongeveer $20 \%$ en voor zand ongeveer $10 \%$ hoger dan het door de KLW ingeschatte eiwitgehalte. Rekening houdend met de veronderstelde overschatting van het KLW eiwitgehalte in vers gras (voor extensieve bedrijven) is dat verschil nog groter.

Los van de vraag of de data van de Weideman representatief zijn voor 'extensieve' bedrijven kunnen die data ook gebruikt worden om na te gaan of het zinvol is om te werken met een regio-specifieke verhouding tussen N/VEM in kuilgras en N/VEM in vers gras. Omdat gegevens over kuilgras niet door de Weideman worden gegeven wordt eerst vastgesteld of er (regio) verschillen bestaan in de N/VEM in vers gras (figuur 5.1).

Figuur 5.1 Verloop in N/VEM vers gras in het weideseizoen van 2015 en 2016. Berekeningen op basis van data van de Weideman en weergegeven per regio en grondsoort.
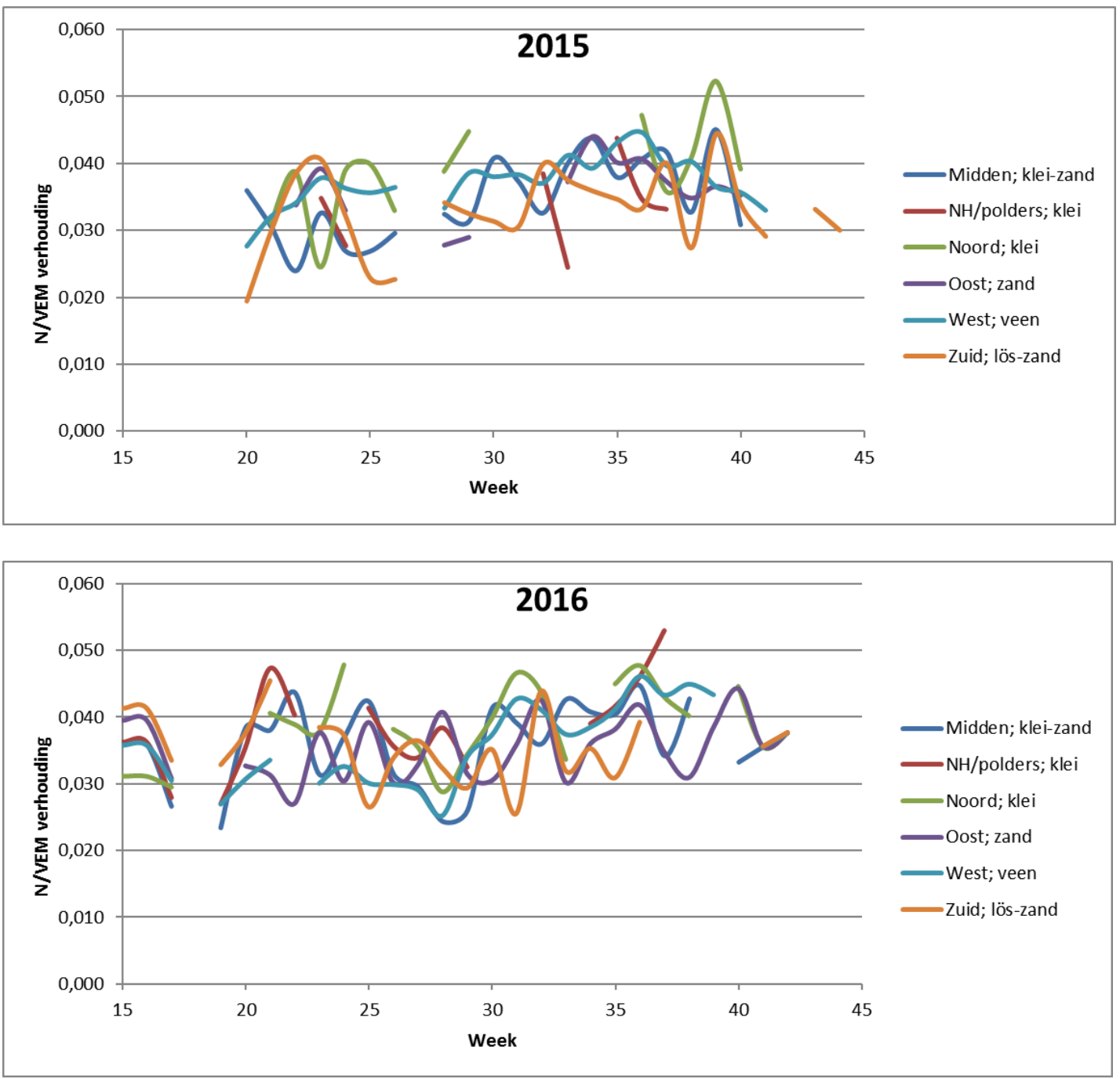

Uit figuur 5.1 blijkt dat N/VEM verhouding in vers gras voor alle regio's niet alleen sterk varieert gedurende het jaar, maar ook tussen jaren. Er zijn geen duidelijke patronen in de tijd (seizoenen) 
voor N/VEM, noch over-all noch tussen regio's. Op basis van deze info is het niet mogelijk om een specifieke N/VEM voor seizoen of regio te definiëren. Daarvoor is de dataset te beperkt. Ook is er in de beschikbare dataset weinig verschil tussen regio's in de N/VEM van vers gras (tabel 5.2), zodat ook de vraag of het zinvol is met naar regio gedifferentieerde N/VEM te werken niet beantwoord kan worden.

Tabel 5.2 Verhouding N/VEM in vers gras, berekend op basis van data van de Weideman en weergegeven per regio als jaargemiddelde (Gem) plus variatiecoëfficiënt (VC).

\begin{tabular}{|c|c|c|c|c|c|c|}
\hline \multirow{3}{*}{ Regio } & \multicolumn{6}{|c|}{2015} \\
\hline & \multicolumn{2}{|c|}{$\mathbf{R E}$} & \multicolumn{2}{|c|}{ VEM } & \multicolumn{2}{|c|}{ N/ VEM } \\
\hline & Gem & VC & Gem & VC & Gem & VC \\
\hline Midden; klei-zand & 212 & $16 \%$ & 980 & $4 \%$ & 0,035 & $17 \%$ \\
\hline NH/polders; klei & 212 & $19 \%$ & 977 & $5 \%$ & 0,035 & $17 \%$ \\
\hline Noord; klei & 248 & $19 \%$ & 984 & $4 \%$ & 0,040 & $19 \%$ \\
\hline Oost; zand & 218 & $15 \%$ & 992 & $4 \%$ & 0,035 & $14 \%$ \\
\hline West; veen & 229 & $9 \%$ & 990 & $3 \%$ & 0,037 & $10 \%$ \\
\hline Zuid; löss-zand & 199 & $19 \%$ & 971 & $4 \%$ & 0,033 & $19 \%$ \\
\hline \multirow[t]{4}{*}{ Over-all gemiddeld } & 220 & & 982 & & 0,036 & \\
\hline & \multicolumn{6}{|c|}{2016} \\
\hline & \multicolumn{2}{|c|}{$\mathbf{R E}$} & \multicolumn{2}{|c|}{ VEM } & \multicolumn{2}{|c|}{ N/ VEM } \\
\hline & Gem & VC & Gem & VC & Gem & VC \\
\hline Midden; klei-zand & 219 & $16 \%$ & 983 & $4 \%$ & 0,036 & $17 \%$ \\
\hline $\mathrm{NH} /$ polders; klei & 238 & $15 \%$ & 992 & $4 \%$ & 0,039 & $17 \%$ \\
\hline Noord; klei & 237 & $15 \%$ & 990 & $3 \%$ & 0,038 & $16 \%$ \\
\hline Oost; zand & 220 & $14 \%$ & 992 & $3 \%$ & 0,035 & $13 \%$ \\
\hline West; veen & 221 & $16 \%$ & 992 & $4 \%$ & 0,036 & $16 \%$ \\
\hline Zuid; löss-zand & 218 & $15 \%$ & 978 & $4 \%$ & 0,036 & $14 \%$ \\
\hline Over-all gemiddeld & 226 & & 988 & & 0,037 & \\
\hline
\end{tabular}

Uit tabel 5.2 blijkt dat het berekende jaargemiddelde voor de N/VEM verhouding in vers gras in 2015 en 2016 varieerde tussen de 0,033 en 0,040 (en verschil van ca. 15\%). Deze variatie is vooral gekoppeld aan het eiwitgehalte in vers gras, omdat de variatiecoëfficiënt voor VEM beduidend kleiner is dan de VC voor eiwit en N/VEM. Het verschil in over-all jaargemiddelden van 2015 en 2016 lijkt met 0,001 weinig en binnen een jaar kan het verschil tussen regio's en het over-all gemiddelde wat groter zijn (0,003 in 2015 en 0,002 in 2016). Echter een verschil van 0,001 in N/VEM geeft in de KLW een verschil van ca. 5-7\% in eiwitgehalte vers gras en dat kan tot relevante verschillen in berekende kengetallen leiden. Het is daarom belangrijk om differentiatie van N/VEM verder uit te werken.

Uit figuur 5.1 en tabel 5.2 blijkt dat het lastig is om aanknopingspunten te vinden voor aanpassing van wijze waarop de KLW de samenstelling van vers gras bepaald. De samenstelling van vers gras (VEMgehalte en eiwitgehalte) vertoont veel variatie gedurende het seizoen en dit is voor alle regio's het geval. De variatieschommelingen vertonen verschillende patronen per regio en binnen een regio verschillen de patronen tussen jaren. Op basis van die informatie kan geen gemiddelde vers gras samenstelling voor een seizoen of regio worden afgeleid en dus ook geen seizoen of regio N/VEM verhouding als differentiatie voor de door de KLW gebruikte standaard N/VEM verhouding. De resultaten laten echter ook zien dat een differentiatie van N/VEM impact zal hebben op de door de KLW berekende kengetallen. Om aan die differentiatie invulling te kunnen geven zijn meer gegevens nodig; aanvulling met het $\mathrm{P}$-gehalte in gras en de mogelijkheid om een relatie te leggen met de samenstelling van aangelegde kuilen. Voor uitwerking van deze aanpak is een bredere inspanning nodig die vraagt om een projectmatige aanpak. 


\subsection{Samenvatting verbetering KLW}

De resultaten van de KLW kunnen verbeterd worden als het gaat om het beter aansluiten bij de praktijkwaarnemingen op de $20 \%$ bedrijven waarvoor bij de validatie KLW niet vastgesteld kon worden of de KLW een representatieve berekening maakt. Het betreft daarbij het vaststellen/berekenen van de volgende 5 parameters:

- VEM-behoefte

- Diergewicht

- P-gehalte melk

- $\quad$ N-gehalte vers gras

- $\quad$ P-gehalte vers gras

VEM-behoefte

De mogelijkheden voor verbetering van de VEM-behoefte-berekening voor melktypische rassen zijn inmiddels belegd in een project dat zich richt op HF koeien. De mogelijkheden voor verbetering voor de dubbeldoelrassen zijn geïdentificeerd en daarvoor wordt onderzocht of ze belegd kunnen worden in een project.

\section{Diergewicht}

Het diergewicht heeft een duidelijk invloed op de door de KLW berekende kengetallen. In de KLW is er voor diergewicht een beperkte differentiatie naar type koe. Dat zou bedrijfsspecifiek ingevuld moeten worden, maar borging is moeilijk. Daarvoor is extra aandacht nodig, bijvoorbeeld via een project.

Wat direct door de werkgroep 'Doorontwikkelen KLW' is opgepakt is het updaten van het gemiddelde gewicht voor de categorie 'overige rassen'. Dit zal worden aangepast conform de huidige CVB-norm. De categorie 'overige rassen' gaat daarmee van $600 \mathrm{~kg}$ naar $650 \mathrm{~kg}$ en de categorie 'kruising Jersey/overige rassen' van 500 kg naar 525 kg. De categorie 'Jersey' blijft ongewijzigd.

P-gehalte melk

De beste verbetering van de KLW voor het P-gehalte in melk is bedrijfsspecifieke bepaling. Daarvoor is in principe een methode beschikbaar (MIRS), maar die is nog niet praktijkrijp. De werkgroep 'Doorontwikkelen KLW' ziet het belang van een bedrijfsspecifieke bepaling van het P-gehalte in melk en zal zich inspannen om het praktijkrijp maken van de MIRS-methodiek op de agenda te zetten.

\section{Samenstelling vers gras}

De samenstelling van vers gras (VEM-gehalte en eiwitgehalte) vertoont veel variatie gedurende het seizoen. De variatieschommelingen lijken niet constant in de tijd, zodat differentiatie van de in de KLW gebruikte N/VEM verhouding (die gerelateerd wordt aan die van graskuil) een brede inspanning vraagt die projectmatig moet worden aangepakt. 


\section{Bijlage 1 Gevoeligheidsanalyse gemiddelde Nederlandse melkveebedrijf}

Effect van aanpassing van enkele parameters van de KLW op de KLW-kengetallen voor het gemiddelde van 1068 bedrijven die representatief zijn voor Nederland. Voor iedere parameter is de doorgerekende aanpassing in de kopregel aangegeven. De effecten van die aanpassing op de berekende waarde van de kengetallen zijn uitgedrukt in een voor dat kengetal logische eenheid. Relevante verschillen zijn gemarkeerd,

\begin{tabular}{|c|c|c|c|c|c|c|c|c|c|}
\hline \multicolumn{2}{|c|}{ Kengetal Kringloopwijzer } & \multicolumn{8}{|c|}{ Parameter } \\
\hline & & 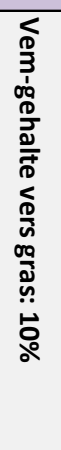 & 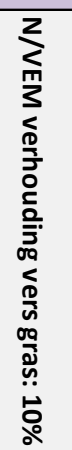 & 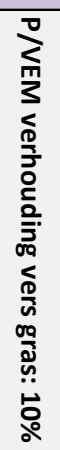 & 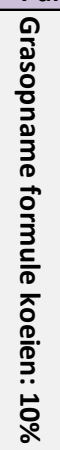 & 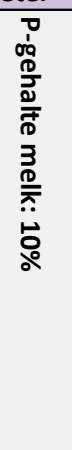 & 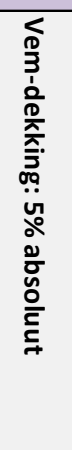 & 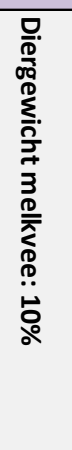 & 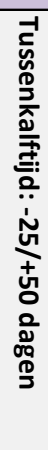 \\
\hline \multirow[t]{2}{*}{ BEX } & \multirow{2}{*}{$\begin{array}{l}\text { Bedrijfspec. excr. stikstof (\%) } \\
\text { Bedrijfspec. excr. fosfaat (\%) }\end{array}$} & 0 & 1 & 0 & 0 & 0 & 6 & 2 & 0 \\
\hline & & 0 & 0 & 1 & 0 & 4 & 7 & 2 & 0 \\
\hline \multirow[t]{2}{*}{ Mestafzet } & \multirow{2}{*}{$\begin{array}{l}\text { Mestafzet stikstof }(\mathrm{kg}) \\
\text { Mestafzet fosfaat }(\mathrm{kg})\end{array}$} & 29 & 173 & 0 & 29 & 0 & 964 & 301 & 2 \\
\hline & & 3 & 0 & 45 & 3 & 181 & 319 & 81 & 2 \\
\hline \multirow[t]{2}{*}{ Opname } & \multirow{2}{*}{$\begin{array}{l}\text { Stikstof-opname rantsoen (\%) } \\
\text { P-opname rantsoen (\%) }\end{array}$} & 0 & 1 & 0 & 0 & 0 & 5 & 2 & 0 \\
\hline & & 0 & 0 & 1 & 0 & 0 & 5 & 2 & 0 \\
\hline \multirow[t]{4}{*}{ Vastlegging } & \multirow{4}{*}{$\begin{array}{l}\text { Melk stikstof (\%) } \\
\text { Melk Fosfaat (\%) } \\
\text { Dieren stikstof (\%) } \\
\text { Dieren Fosfaat (\%) }\end{array}$} & 0 & 0 & 0 & 0 & 0 & 0 & 0 & 0 \\
\hline & & 0 & 0 & 0 & 0 & 10 & 0 & 0 & 0 \\
\hline & & 0 & 0 & 0 & 0 & 0 & 0 & 3 & 0 \\
\hline & & 0 & 0 & 0 & 0 & 0 & 0 & 3 & 0 \\
\hline \multirow[t]{2}{*}{ Bedrijfsoverschot } & \multirow{2}{*}{$\begin{array}{l}\text { Kg stikstof per ha }(\mathrm{kg}) \\
\text { Kg fosfaat per ha }(\mathrm{kg})\end{array}$} & 0 & 0 & 0 & 0 & 0 & 2 & 1 & 0 \\
\hline & & 0 & 0 & 0 & 0 & 4 & 1 & 1 & 0 \\
\hline \multirow[t]{2}{*}{ Efficiëntie voeding } & \multirow{2}{*}{$\begin{array}{l}\text { Benutting: stikstof (\%,abs) } \\
\text { Benutting: fosfaat (\%,abs) }\end{array}$} & 0 & 0 & 0 & 0 & 0 & 1 & 0 & 0 \\
\hline & & 0 & 0 & 0 & 0 & 3 & 1 & 0 & 0 \\
\hline \multirow[t]{3}{*}{ Opbrengst grasland } & \multirow{3}{*}{$\begin{array}{l}\text { Kg drogestof per ha (\%) } \\
\text { Kg stikstof per ha (\%) } \\
\text { Kg fosfaat per ha (\%) }\end{array}$} & 1 & 0 & 0 & 0 & 0 & 7 & 3 & 0 \\
\hline & & 0 & 2 & 0 & 0 & 0 & 7 & 3 & 0 \\
\hline & & 0 & 0 & 2 & 0 & 0 & 7 & 3 & 0 \\
\hline \multirow{3}{*}{\multicolumn{2}{|c|}{$\begin{array}{r}\text { Opbrengst maïsland } \mathrm{Kg} \text { drogestof per ha (\%) } \\
\qquad \begin{array}{r}\mathrm{Kg} \text { stikstof per ha (\%) } \\
\mathrm{Kg} \text { fosfaat per ha (\%) }\end{array} \\
\end{array}$}} & 1 & 0 & 0 & 1 & 0 & 6 & 2 & 0 \\
\hline & & 1 & 0 & 0 & 1 & 0 & 6 & 2 & 0 \\
\hline & & 1 & 0 & 0 & 1 & 0 & 6 & 2 & 0 \\
\hline \multirow[t]{3}{*}{ Bodemoverschot } & \multirow{3}{*}{$\begin{array}{l}\text { Kg stikstof per ha (kg) } \\
\text { Kg fosfaat per ha (kg) } \\
\text { Kg aanvoer eff. org.stof per ha (\%) }\end{array}$} & 0 & 1 & 0 & 0 & 0 & 3 & 2 & 0 \\
\hline & & 0 & 0 & 0 & 0 & 4 & 1 & 1 & 0 \\
\hline & & 0 & 1 & 0 & 0 & 0 & 5 & 2 & 0 \\
\hline \multirow[t]{2}{*}{ Efficiëntie bodem } & \multirow{2}{*}{$\begin{array}{l}\text { Benutting: stikstof (\%, abs) } \\
\text { Benutting: fosfaat }(\%, \text { abs })\end{array}$} & 0 & 1 & 0 & 0 & 0 & 2 & 1 & 0 \\
\hline & & 0 & 0 & 0 & 0 & 5 & 2 & 0 & 0 \\
\hline \multirow[t]{3}{*}{ Ammoniakemissie } & \multirow{3}{*}{$\begin{array}{l}\text { kg per bedrijf (\%) } \\
\text { Kg per GVE: stal en mestopslag (\%) } \\
\text { Kg per GVE: overige verliezen (\%) }\end{array}$} & 1 & 2 & 0 & 0 & 0 & 7 & 2 & 0 \\
\hline & & 1 & 2 & 0 & 0 & 0 & 7 & 2 & 0 \\
\hline & & 1 & 2 & 0 & 0 & 0 & 7 & 2 & 0 \\
\hline \multirow[t]{3}{*}{ Broeikasgassen } & \multirow{3}{*}{$\begin{array}{l}\text { Kg methaan per ton melk (\%) } \\
\text { Kg lachgas per ton melk (\%) } \\
\text { Kg CO2 per ton melk (\%) }\end{array}$} & 1 & 0 & 0 & 0 & 0 & 6 & 2 & 0 \\
\hline & & 0 & 1 & 0 & 0 & 0 & 3 & 1 & 0 \\
\hline & & 1 & 0 & 0 & 1 & 0 & 5 & 2 & 0 \\
\hline
\end{tabular}




\section{Bijlage 2 Gevoeligheidsanalyse gemiddelde 'extensieve' melkveebedrijf}

Effect van aanpassing van enkele parameters van de KLW op de KLW-kengetallen voor het gemiddelde van de 13 deelnemende 'extensieve' bedrijven. Voor iedere parameter is de doorgerekende aanpassing in de kopregel aangegeven. De effecten van die aanpassing op de berekende waarde van de kengetallen zijn uitgedrukt in een voor dat kengetal logische eenheid. Relevante verschillen zijn gemarkeerd.

\begin{tabular}{|c|c|c|c|c|c|c|c|c|c|}
\hline \multicolumn{2}{|c|}{ Kengetal Kringloopwijzer } & \multicolumn{8}{|c|}{ Parameter } \\
\hline & & 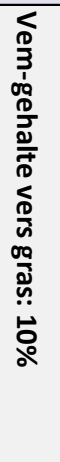 & 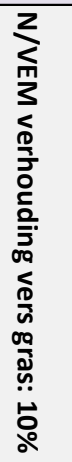 & 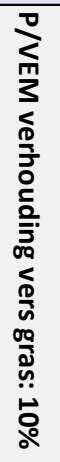 & 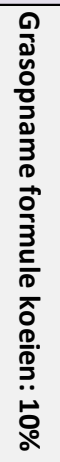 & 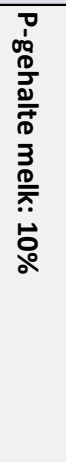 & 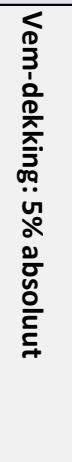 & 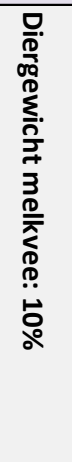 & 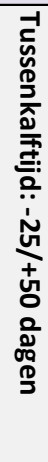 \\
\hline \multirow[t]{2}{*}{ BEX } & Bedrijfspec. excr. stikstof (\%) & 0 & 3 & 0 & 0 & 0 & 6 & 2 & 0 \\
\hline & Bedrijfspec. excr. fosfaat (\%) & 0 & 0 & 2 & 0 & 3 & 7 & 2 & 0 \\
\hline \multirow[t]{2}{*}{ Mestafzet } & Mestafzet stikstof (kg) & 27 & 284 & 0 & 27 & 0 & 705 & 242 & 1 \\
\hline & Mestafzet fosfaat (kg) & 2 & 0 & 91 & 2 & 143 & 279 & 84 & 1 \\
\hline \multirow[t]{2}{*}{ Opname } & Stikstof-opname rantsoen (\%) & 0 & 2 & 0 & 0 & 0 & 5 & 2 & 0 \\
\hline & P-opname rantsoen (\%) & 0 & 0 & 2 & 0 & 0 & 5 & 2 & 0 \\
\hline \multirow[t]{4}{*}{ Vastlegging } & Melk stikstof (\%) & 0 & 0 & 0 & 0 & 0 & 0 & 0 & 0 \\
\hline & Melk Fosfaat (\%) & 0 & 0 & 0 & 0 & 10 & 0 & 0 & 0 \\
\hline & Dieren stikstof (\%) & 0 & 0 & 0 & 0 & 0 & 0 & 3 & 0 \\
\hline & Dieren Fosfaat (\%) & 0 & 0 & 0 & 0 & 0 & 0 & 3 & 0 \\
\hline \multirow[t]{2}{*}{ Bedrijfsoverschot } & Kg stikstof per ha (kg) & 0 & 0 & 0 & 0 & 0 & 1 & 1 & 0 \\
\hline & Kg fosfaat per ha $(\mathrm{kg})$ & 0 & 0 & 0 & 0 & 3 & 0 & 1 & 0 \\
\hline \multirow[t]{2}{*}{ Efficiëntie voeding } & Benutting: stikstof (\%,abs) & 0 & 0 & 0 & 0 & 0 & 1 & 0 & 0 \\
\hline & Benutting: fosfaat $(\%, a b s)$ & 0 & 0 & 0 & 0 & 2 & 1 & 0 & 0 \\
\hline \multirow[t]{3}{*}{ Opbrengst grasland } & Kg drogestof per ha (\%) & 2 & 0 & 0 & 0 & 0 & 7 & 3 & 0 \\
\hline & Kg stikstof per ha (\%) & 0 & 3 & 0 & 0 & 0 & 7 & 3 & 0 \\
\hline & Kg fosfaat per ha (\%) & 0 & 0 & 3 & 0 & 0 & 7 & 3 & 0 \\
\hline \multirow[t]{3}{*}{ Opbrengst maïsland } & Kg drogestof per ha (\%) & 1 & 0 & 0 & 1 & 0 & 3 & 1 & 0 \\
\hline & Kg stikstof per ha (\%) & 1 & 0 & 0 & 1 & 0 & 3 & 1 & 0 \\
\hline & Kg fosfaat per ha (\%) & 1 & 0 & 0 & 1 & 0 & 3 & 1 & 0 \\
\hline \multirow[t]{3}{*}{ Bodemoverschot } & Kg stikstof per ha $(\mathrm{kg})$ & 1 & 2 & 0 & 0 & 0 & 4 & 2 & 0 \\
\hline & Kg fosfaat per ha $(\mathrm{kg})$ & 0 & 0 & 0 & 0 & 3 & 0 & 1 & 0 \\
\hline & Kg aanvoer eff. org.stof per ha (\%) & 0 & 2 & 0 & 0 & 0 & 5 & 2 & 0 \\
\hline \multirow[t]{2}{*}{ Efficiëntie bodem } & Benutting: stikstof (\%, abs) & 0 & 1 & 0 & 0 & 0 & 2 & 1 & 0 \\
\hline & Benutting: fosfaat (\%, abs) & 0 & 0 & 0 & 0 & 4 & 1 & 1 & 0 \\
\hline \multirow[t]{3}{*}{ Ammoniakemissie } & kg per bedrijf (\%) & 1 & 3 & 0 & 0 & 0 & 7 & 2 & 0 \\
\hline & Kg per GVE: stal en mestopslag (\%) & 1 & 3 & 0 & 0 & 0 & 7 & 2 & 0 \\
\hline & Kg per GVE: overige verliezen (\%) & 1 & 3 & 0 & 0 & 0 & 7 & 2 & 0 \\
\hline \multirow[t]{3}{*}{ Broeikasgassen } & Kg methaan per ton melk (\%) & 1 & 1 & 0 & 0 & 0 & 6 & 2 & 0 \\
\hline & Kg lachgas per ton melk (\%) & 0 & 2 & 0 & 0 & 0 & 4 & 1 & 0 \\
\hline & $\mathrm{Kg} \mathrm{CO} 2$ per ton melk (\%) & 1 & 0 & 0 & 1 & 0 & 5 & 2 & 0 \\
\hline
\end{tabular}




\section{Bijlage 3 Gevoeligheidsanalyse individuele 'extensieve' melkveebedrijf}

Effect van aanpassing van enkele parameters van de KLW op de KLW-kengetallen voor ieder deelnemend bedrijf afzonderlijk. Voor iedere parameter is de doorgerekende aanpassing in de kopregel aangegeven. De effecten van die aanpassing op de berekende waarde van de kengetallen kunnen afgeleid worden door het resultaat per parameter te vergelijken met de waarde in de uitgangssituatie (= standaard KLW) in de eerste kolom onder de kop 'Parameter'. Voor de betreffende ondernemer relevante verschillen zijn gemarkeerd (geel duidelijk relevant en roze bij twijfel)

\begin{tabular}{|c|c|c|c|c|c|c|c|c|c|c|c|c|c|c|c|c|c|}
\hline \multirow[t]{2}{*}{ Bedrijf } & \multicolumn{2}{|r|}{ Kengetallen Kringloopwijzer } & \multicolumn{15}{|c|}{ Parameter } \\
\hline & & & 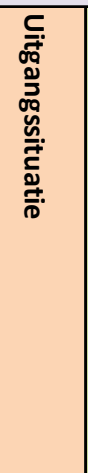 & 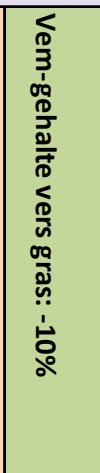 & 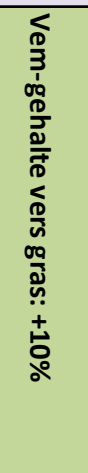 & 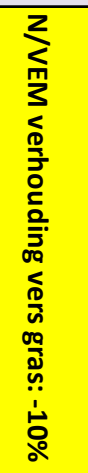 & 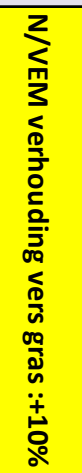 & 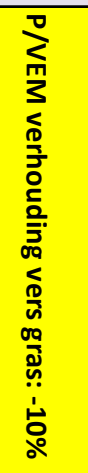 & 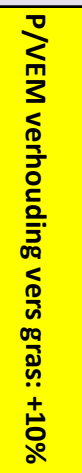 & 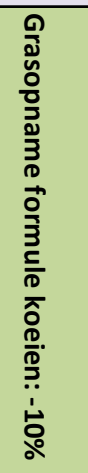 & 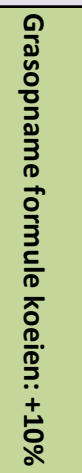 & 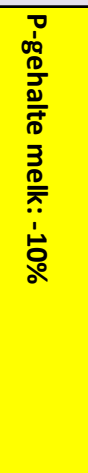 & 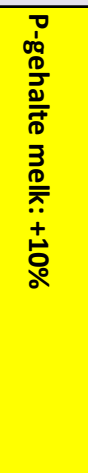 & 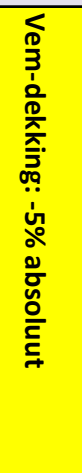 & 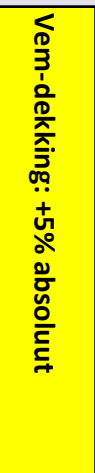 & 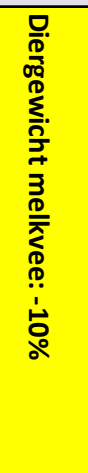 & 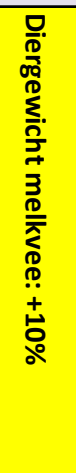 \\
\hline \multirow[t]{8}{*}{1} & BEX & Voordeel bedrijfspecifiek excretie: stikstof & $-6 \%$ & $-5 \%$ & $-6 \%$ & $0 \%$ & $-11 \%$ & $-6 \%$ & $-6 \%$ & $-5 \%$ & $-6 \%$ & $-6 \%$ & $-6 \%$ & $1 \%$ & $-13 \%$ & $-4 \%$ & $-8 \%$ \\
\hline & & Voordeel bedrijfspecifiek excretie: fosfaat & $-3 \%$ & $-4 \%$ & $-3 \%$ & $-3 \%$ & $-3 \%$ & $2 \%$ & $-8 \%$ & $-4 \%$ & $-3 \%$ & $-7 \%$ & $0 \%$ & $3 \%$ & $-10 \%$ & $-1 \%$ & $-5 \%$ \\
\hline & Opbrengst grasland & Opbrengst netto per ha: droge stof ( $\mathrm{kg} \mathrm{ds}$ ) & 9640 & 10089 & 9237 & 9640 & 9640 & 9640 & 9640 & 9709 & 9577 & 9640 & 9640 & 9084 & 10196 & 9420 & 9855 \\
\hline & Opbrengst maisland & Opbrengst netto per ha: droge stof ( $\mathrm{kg} \mathrm{ds}$ ) & 0 & 0 & 0 & 0 & 0 & 0 & 0 & 0 & 0 & 0 & 0 & 0 & 0 & 0 & 0 \\
\hline & Bodemoverschot & Overschot per ha: stikstof (kg N) & -53 & -53 & -54 & -49 & -58 & -53 & -53 & -53 & -54 & -53 & -53 & -48 & -59 & -51 & -56 \\
\hline & & Overschot per ha: fosfaat (kg P2O5) & -21 & -21 & -21 & -21 & -21 & -21 & -21 & -21 & -21 & -19 & -23 & -21 & -21 & -21 & -21 \\
\hline & Ammoniak & Emissie per bedrijf: totaal (kg NH3) & 2784 & 2749 & 2819 & 2571 & 3000 & 2784 & 2784 & 2761 & 2805 & 2784 & 2784 & 2547 & 3022 & 2703 & 2862 \\
\hline & Broeikasgassen & Emissie per ton melk: totaal bedrijf ( $\mathrm{kg} \mathrm{CO2-eq)}$ & 1318 & 1348 & 1291 & 1301 & 1335 & 1318 & 1318 & 1323 & 1313 & 1318 & 1318 & 1258 & 1378 & 1295 & 1340 \\
\hline
\end{tabular}




\begin{tabular}{|c|c|c|c|c|c|c|c|c|c|c|c|c|c|c|c|c|c|}
\hline \multirow[t]{2}{*}{ Bedrijf } & \multicolumn{2}{|r|}{ Kengetallen Kringloopwijzer } & \multicolumn{15}{|c|}{ Parameter } \\
\hline & & & 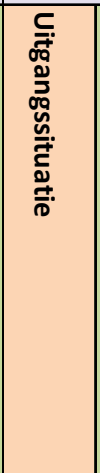 & 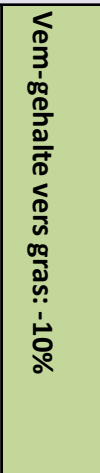 & 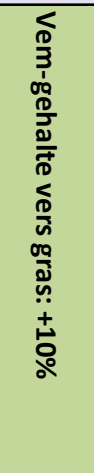 & 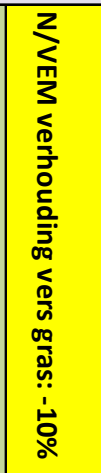 & 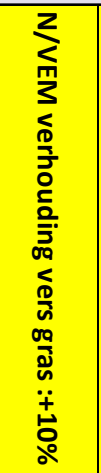 & 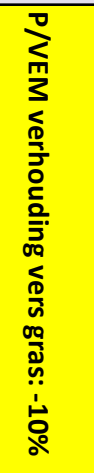 & 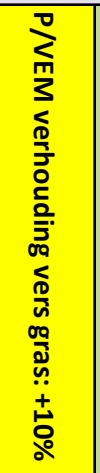 & 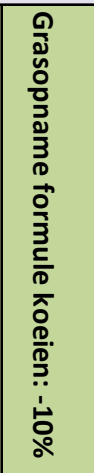 & 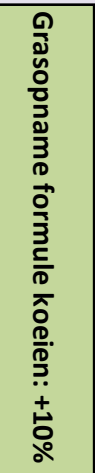 & 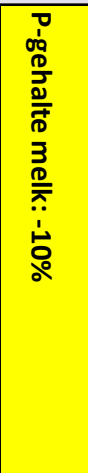 & 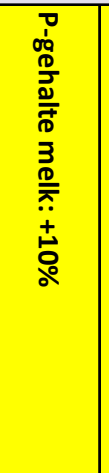 & 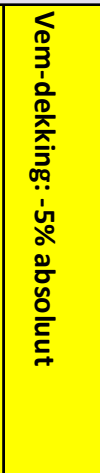 & 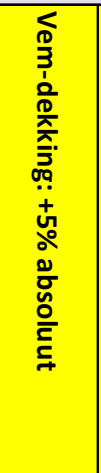 & 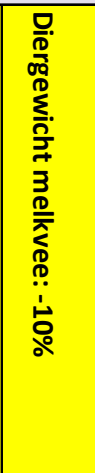 & 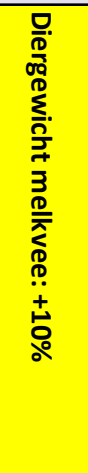 \\
\hline \multirow[t]{8}{*}{2} & BEX & Voordeel bedrijfspecifiek excretie: stikstof & $-4 \%$ & $-4 \%$ & $-4 \%$ & $0 \%$ & $-7 \%$ & $-4 \%$ & $-4 \%$ & $-4 \%$ & $-4 \%$ & $-4 \%$ & $-4 \%$ & $3 \%$ & $-10 \%$ & $-2 \%$ & $-6 \%$ \\
\hline & & Voordeel bedrijfspecifiek excretie: fosfaat & $-17 \%$ & $-17 \%$ & $-17 \%$ & $-17 \%$ & $-17 \%$ & $-13 \%$ & $-21 \%$ & $-17 \%$ & $-17 \%$ & $-20 \%$ & $-13 \%$ & $-9 \%$ & $-25 \%$ & $-15 \%$ & $-19 \%$ \\
\hline & Opbrengst grasland & Opbrengst netto per ha: droge stof (kg ds) & 13854 & 14342 & 13403 & 13854 & 13854 & 13854 & 13854 & 13952 & 13762 & 13854 & 13854 & 12916 & 14792 & 13499 & 14201 \\
\hline & Opbrengst maisland & Opbrengst netto per ha: droge stof (kg ds) & 0 & 0 & 0 & 0 & 0 & 0 & 0 & 0 & 0 & 0 & 0 & 0 & 0 & 0 & 0 \\
\hline & Bodemoverschot & Overschot per ha: stikstof ( $\mathrm{kg} \mathrm{N}$ ) & 174 & 173 & 174 & 176 & 171 & 174 & 174 & 173 & 174 & 174 & 174 & 179 & 168 & 176 & 171 \\
\hline & & Overschot per ha: fosfaat (kg P2O5) & -18 & -19 & -18 & -18 & -18 & -18 & -18 & -19 & -18 & -15 & -22 & -18 & -19 & -17 & -19 \\
\hline & Ammoniak & Emissie per bedrijf: totaal (kg NH3) & 3041 & 3020 & 3062 & 2918 & 3166 & 3041 & 3041 & 3030 & 3051 & 3041 & 3041 & 2832 & 3250 & 2978 & 3102 \\
\hline & Broeikasgassen & Emissie per ton melk: totaal bedrijf (kg CO2-eq) & 1477 & 1498 & 1457 & 1467 & 1487 & 1477 & 1477 & 1481 & 1472 & 1477 & 1477 & 1416 & 1538 & 1454 & 1499 \\
\hline \multirow[t]{8}{*}{3} & BEX & Voordeel bedrijfspecifiek excretie: stikstof & $-12 \%$ & $-11 \%$ & $-12 \%$ & $-4 \%$ & $-19 \%$ & $-12 \%$ & $-12 \%$ & $-11 \%$ & $-12 \%$ & $-12 \%$ & $-12 \%$ & $-4 \%$ & $-19 \%$ & $-9 \%$ & $-15 \%$ \\
\hline & & Voordeel bedrijfspecifiek excretie: fosfaat & $6 \%$ & $6 \%$ & $6 \%$ & $6 \%$ & $6 \%$ & $13 \%$ & $0 \%$ & $6 \%$ & $6 \%$ & $3 \%$ & $10 \%$ & $14 \%$ & $-1 \%$ & $9 \%$ & $4 \%$ \\
\hline & Opbrengst grasland & Opbrengst netto per ha: droge stof (kg ds) & 10595 & 11243 & 10027 & 10595 & 10595 & 10595 & 10595 & 10540 & 10646 & 10595 & 10595 & 9927 & 11264 & 10306 & 10877 \\
\hline & Opbrengst maisland & Opbrengst netto per ha: droge stof (kg ds) & 0 & 0 & 0 & 0 & 0 & 0 & 0 & 0 & 0 & 0 & 0 & 0 & 0 & 0 & 0 \\
\hline & Bodemoverschot & Overschot per ha: stikstof (kg N) & 134 & 138 & 130 & 138 & 129 & 134 & 134 & 136 & 131 & 134 & 134 & 134 & 133 & 134 & 133 \\
\hline & & Overschot per ha: fosfaat (kg P2O5) & -8 & -7 & -9 & -8 & -8 & -8 & -8 & -7 & -9 & -5 & -11 & -9 & -7 & -8 & -8 \\
\hline & Ammoniak & Emissie per bedrijf: totaal (kg NH3) & 3050 & 3011 & 3090 & 2810 & 3296 & 3050 & 3050 & 3028 & 3070 & 3050 & 3050 & 2822 & 3279 & 2960 & 3139 \\
\hline & Broeikasgassen & Emissie per ton melk: totaal bedrijf (kg CO2-eq) & 1381 & 1414 & 1352 & 1360 & 1401 & 1381 & 1381 & 1383 & 1379 & 1381 & 1381 & 1323 & 1439 & 1356 & 1405 \\
\hline
\end{tabular}




\begin{tabular}{|c|c|c|c|c|c|c|c|c|c|c|c|c|c|c|c|c|c|}
\hline \multirow[t]{2}{*}{ Bedrijf } & \multicolumn{2}{|r|}{ Kengetallen Kringloopwijzer } & \multicolumn{15}{|c|}{ Parameter } \\
\hline & & & 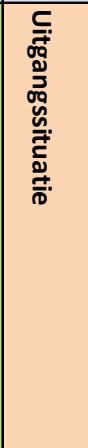 & 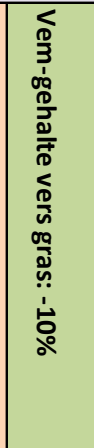 & 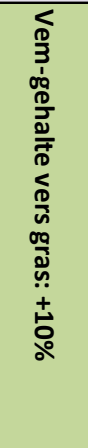 & 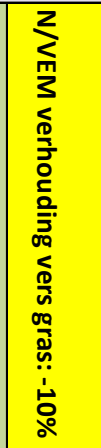 & 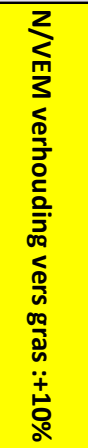 & 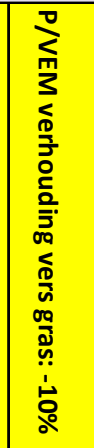 & 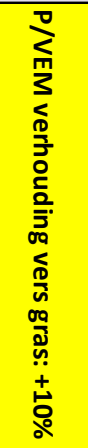 & 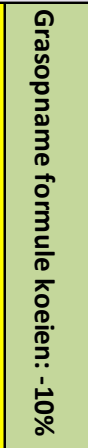 & 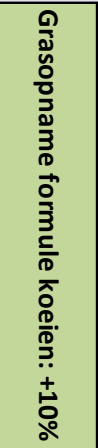 & 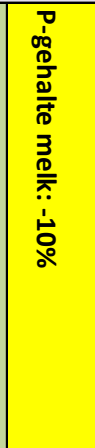 & 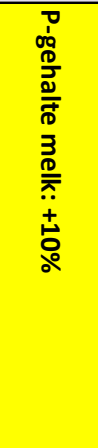 & 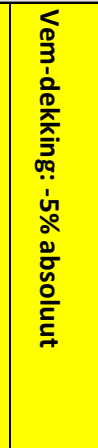 & 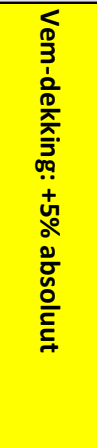 & 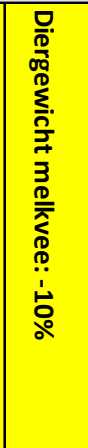 & 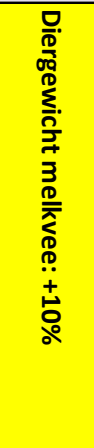 \\
\hline \multirow[t]{8}{*}{4} & BEX & Voordeel bedrijfspecifiek excretie: stikstof & $6 \%$ & $6 \%$ & $6 \%$ & $6 \%$ & $6 \%$ & $6 \%$ & $6 \%$ & $6 \%$ & $6 \%$ & $6 \%$ & $6 \%$ & $12 \%$ & $1 \%$ & $8 \%$ & $4 \%$ \\
\hline & & Voordeel bedrijfspecifiek excretie: fosfaat & $-3 \%$ & $-3 \%$ & $-3 \%$ & $-3 \%$ & $-3 \%$ & $-3 \%$ & $-3 \%$ & $-3 \%$ & $-3 \%$ & $-6 \%$ & $0 \%$ & $4 \%$ & $-9 \%$ & $-1 \%$ & $-4 \%$ \\
\hline & Opbrengst grasland & Opbrengst netto per ha: droge stof (kg ds) & 15318 & 15328 & 15310 & 15318 & 15318 & 15318 & 15318 & 15318 & 15318 & 15318 & 15318 & 14298 & 16338 & 14953 & 15672 \\
\hline & Opbrengst maisland & Opbrengst netto per ha: droge stof (kg ds) & 27970 & 27970 & 27970 & 27970 & 27970 & 27970 & 27970 & 27970 & 27970 & 27970 & 27970 & 26096 & 29843 & 27299 & 28620 \\
\hline & Bodemoverschot & Overschot per ha: stikstof (kg N) & 44 & 44 & 44 & 45 & 44 & 44 & 44 & 44 & 44 & 44 & 44 & 50 & 38 & 47 & 42 \\
\hline & & Overschot per ha: fosfaat (kg P2O5) & -25 & -25 & -25 & -25 & -25 & -25 & -25 & -25 & -25 & -21 & -29 & -25 & -25 & -24 & -26 \\
\hline & Ammoniak & Emissie per bedrijf: totaal (kg NH3) & 1707 & 1707 & 1707 & 1707 & 1707 & 1707 & 1707 & 1707 & 1707 & 1707 & 1707 & 1584 & 1830 & 1670 & 1742 \\
\hline & Broeikasgassen & Emissie per ton melk: totaal bedrijf (kg CO2-eq) & 1555 & 1555 & 1555 & 1555 & 1555 & 1555 & 1555 & 1555 & 1555 & 1555 & 1555 & 1491 & 1619 & 1532 & 1576 \\
\hline \multirow[t]{8}{*}{5} & BEX & Voordeel bedrijfspecifiek excretie: stikstof & $3 \%$ & $3 \%$ & $3 \%$ & $5 \%$ & $2 \%$ & $3 \%$ & $3 \%$ & $3 \%$ & $3 \%$ & $3 \%$ & $3 \%$ & $10 \%$ & $-3 \%$ & $5 \%$ & $1 \%$ \\
\hline & & Voordeel bedrijfspecifiek excretie: fosfaat & $-5 \%$ & $-5 \%$ & $-5 \%$ & $-5 \%$ & $-5 \%$ & $-3 \%$ & $-6 \%$ & $-5 \%$ & $-5 \%$ & $-9 \%$ & $-1 \%$ & $3 \%$ & $-13 \%$ & $-3 \%$ & $-7 \%$ \\
\hline & Opbrengst grasland & Opbrengst netto per ha: droge stof ( $\mathrm{kg} \mathrm{ds}$ ) & 9761 & 9942 & 9597 & 9761 & 9761 & 9761 & 9761 & 9772 & 9751 & 9761 & 9761 & 9002 & 10520 & 9471 & 10044 \\
\hline & Opbrengst maisland & Opbrengst netto per ha: droge stof (kg ds) & 0 & 0 & 0 & 0 & 0 & 0 & 0 & 0 & 0 & 0 & 0 & 0 & 0 & 0 & 0 \\
\hline & Bodemoverschot & Overschot per ha: stikstof (kg N) & 125 & 125 & 124 & 126 & 124 & 125 & 125 & 125 & 125 & 125 & 125 & 127 & 123 & 126 & 123 \\
\hline & & Overschot per ha: fosfaat (kg P2O5) & 9 & 9 & 8 & 9 & 9 & 9 & 8 & 9 & 8 & 11 & 6 & 8 & 9 & 9 & 8 \\
\hline & Ammoniak & Emissie per bedrijf: totaal (kg NH3) & 2126 & 2118 & 2134 & 2084 & 2168 & 2126 & 2126 & 2122 & 2130 & 2126 & 2126 & 1962 & 2290 & 2072 & 2179 \\
\hline & Broeikasgassen & Emissie per ton melk: totaal bedrijf (kg CO2-eq) & 1517 & 1525 & 1510 & 1513 & 1521 & 1517 & 1517 & 1519 & 1516 & 1517 & 1517 & 1462 & 1573 & 1497 & 1538 \\
\hline
\end{tabular}




\begin{tabular}{|c|c|c|c|c|c|c|c|c|c|c|c|c|c|c|c|c|c|}
\hline \multirow[t]{2}{*}{ Bedrijf } & \multicolumn{2}{|r|}{ Kengetallen Kringloopwijzer } & \multicolumn{15}{|c|}{ Parameter } \\
\hline & & & 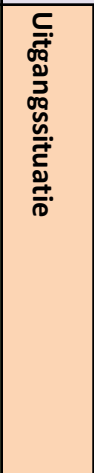 & 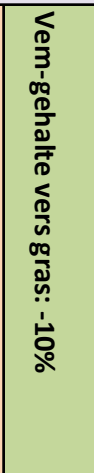 & 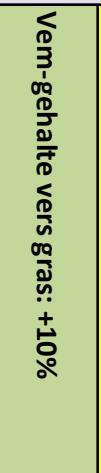 & 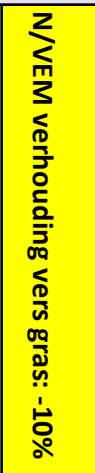 & 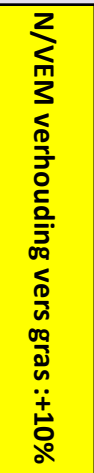 & 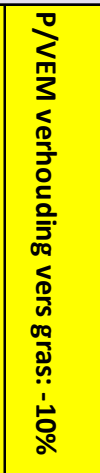 & 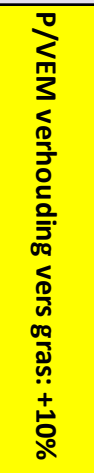 & 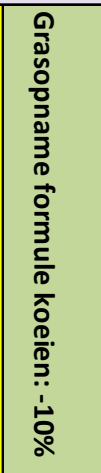 & 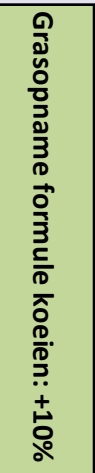 & 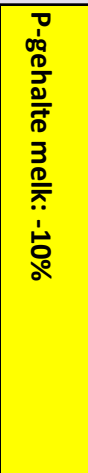 & 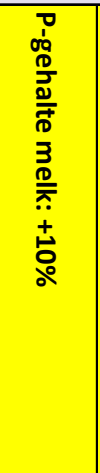 & 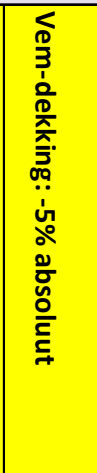 & 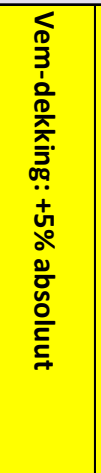 & 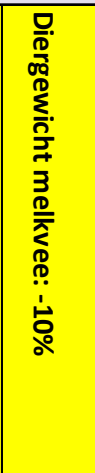 & 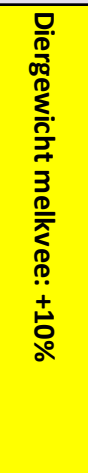 \\
\hline \multirow[t]{8}{*}{6} & BEX & Voordeel bedrijfspecifiek excretie: stikstof & $-1 \%$ & $-1 \%$ & $-1 \%$ & $1 \%$ & $-2 \%$ & $-1 \%$ & $-1 \%$ & $-1 \%$ & $-1 \%$ & $-1 \%$ & $-1 \%$ & $5 \%$ & $-7 \%$ & $1 \%$ & $-3 \%$ \\
\hline & & Voordeel bedrijfspecifiek excretie: fosfaat & $-13 \%$ & $-12 \%$ & $-13 \%$ & $-13 \%$ & $-13 \%$ & $-11 \%$ & $-14 \%$ & $-12 \%$ & $-13 \%$ & $-16 \%$ & $-9 \%$ & $-6 \%$ & $-20 \%$ & $-11 \%$ & $-14 \%$ \\
\hline & Opbrengst grasland & Opbrengst netto per ha: droge stof (kg ds) & 9593 & 9738 & 9453 & 9593 & 9593 & 9593 & 9593 & 9586 & 9599 & 9593 & 9593 & 8895 & 10291 & 9346 & 9834 \\
\hline & Opbrengst maisland & Opbrengst netto per ha: droge stof (kg ds) & 0 & 0 & 0 & 0 & 0 & 0 & 0 & 0 & 0 & 0 & 0 & 0 & 0 & 0 & 0 \\
\hline & Bodemoverschot & Overschot per ha: stikstof (kg N) & 199 & 200 & 199 & 201 & 198 & 199 & 199 & 200 & 199 & 199 & 199 & 203 & 195 & 201 & 197 \\
\hline & & Overschot per ha: fosfaat (kg P2O5) & 15 & 15 & 15 & 15 & 15 & 15 & 15 & 15 & 15 & 18 & 12 & 14 & 15 & 16 & 14 \\
\hline & Ammoniak & Emissie per bedrijf: totaal (kg NH3) & 2923 & 2899 & 2947 & 2865 & 2982 & 2923 & 2923 & 2905 & 2940 & 2923 & 2923 & 2742 & 3104 & 2876 & 2969 \\
\hline & Broeikasgassen & Emissie per ton melk: totaal bedrijf (kg CO2-eq) & 1554 & 1561 & 1547 & 1549 & 1559 & 1554 & 1554 & 1554 & 1553 & 1554 & 1554 & 1495 & 1613 & 1534 & 1573 \\
\hline \multirow[t]{8}{*}{7} & BEX & Voordeel bedrijfspecifiek excretie: stikstof & $8 \%$ & $8 \%$ & $7 \%$ & $9 \%$ & $6 \%$ & $8 \%$ & $8 \%$ & $8 \%$ & $7 \%$ & $8 \%$ & $8 \%$ & $13 \%$ & $2 \%$ & $10 \%$ & $6 \%$ \\
\hline & & Voordeel bedrijfspecifiek excretie: fosfaat & $14 \%$ & $14 \%$ & $14 \%$ & $14 \%$ & $14 \%$ & $15 \%$ & $13 \%$ & $14 \%$ & $14 \%$ & $10 \%$ & $18 \%$ & $20 \%$ & $9 \%$ & $16 \%$ & $12 \%$ \\
\hline & Opbrengst grasland & Opbrengst netto per ha: droge stof ( $\mathrm{kg} \mathrm{ds}$ ) & 10886 & 11030 & 10745 & 10886 & 10886 & 10886 & 10886 & 10877 & 10894 & 10886 & 10886 & 10118 & 11653 & 10550 & 11212 \\
\hline & Opbrengst maisland & Opbrengst netto per ha: droge stof (kg ds) & 0 & 0 & 0 & 0 & 0 & 0 & 0 & 0 & 0 & 0 & 0 & 0 & 0 & 0 & 0 \\
\hline & Bodemoverschot & Overschot per ha: stikstof (kg N) & 182 & 183 & 182 & 183 & 181 & 182 & 182 & 182 & 182 & 182 & 182 & 185 & 179 & 184 & 180 \\
\hline & & Overschot per ha: fosfaat (kg P2O5) & -5 & -4 & -5 & -5 & -5 & -5 & -5 & -4 & -5 & -1 & -8 & -5 & -4 & -4 & -5 \\
\hline & Ammoniak & Emissie per bedrijf: totaal (kg NH3) & 3129 & 3101 & 3158 & 3062 & 3197 & 3129 & 3129 & 3107 & 3150 & 3129 & 3129 & 2906 & 3353 & 3046 & 3210 \\
\hline & Broeikasgassen & Emissie per ton melk: totaal bedrijf ( $\mathrm{kg} \mathrm{CO} 2-e q)$ & 1362 & 1367 & 1356 & 1358 & 1366 & 1362 & 1362 & 1362 & 1362 & 1362 & 1362 & 1311 & 1413 & 1340 & 1383 \\
\hline
\end{tabular}




\begin{tabular}{|c|c|c|c|c|c|c|c|c|c|c|c|c|c|c|c|c|c|}
\hline \multirow{2}{*}{ Bedrijf } & \multicolumn{2}{|r|}{ Kengetallen Kringloopwijzer } & \multicolumn{15}{|c|}{ Parameter } \\
\hline & & & 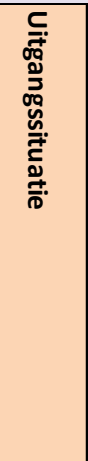 & 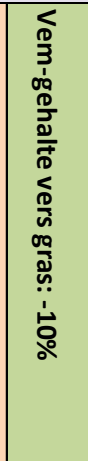 & 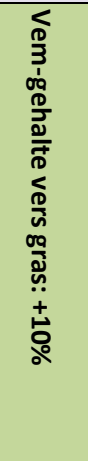 & 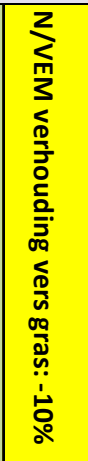 & 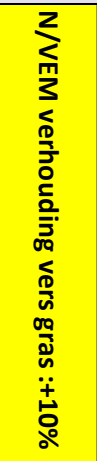 & 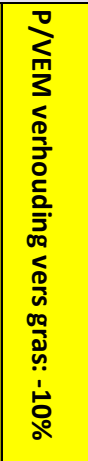 & 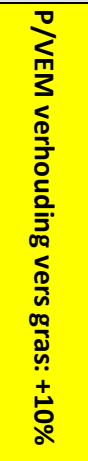 & 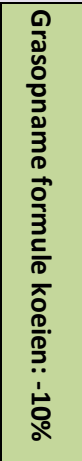 & 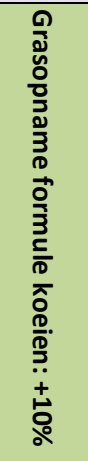 & 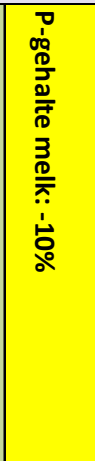 & 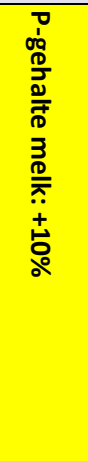 & 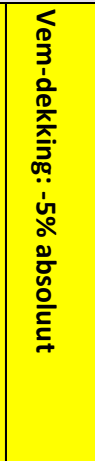 & 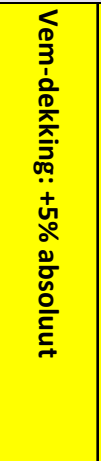 & 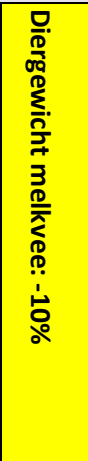 & 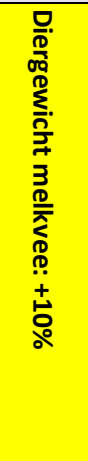 \\
\hline \multirow[t]{8}{*}{8} & BEX & Voordeel bedrijfspecifiek excretie: stikstof & $8 \%$ & $8 \%$ & $7 \%$ & $9 \%$ & $7 \%$ & $8 \%$ & $8 \%$ & $8 \%$ & $7 \%$ & $8 \%$ & $8 \%$ & $13 \%$ & $3 \%$ & $10 \%$ & $6 \%$ \\
\hline & & Voordeel bedrijfspecifiek excretie: fosfaat & $15 \%$ & $15 \%$ & $15 \%$ & $15 \%$ & $15 \%$ & $16 \%$ & $14 \%$ & $15 \%$ & $15 \%$ & $11 \%$ & $19 \%$ & $22 \%$ & $9 \%$ & $17 \%$ & $13 \%$ \\
\hline & Opbrengst grasland & Opbrengst netto per ha: droge stof (kg ds) & 12012 & 12170 & 11858 & 12012 & 12012 & 12012 & 12012 & 11975 & 12047 & 12012 & 12012 & 11058 & 12966 & 11622 & 12392 \\
\hline & Opbrengst maisland & Opbrengst netto per ha: droge stof (kg ds) & 25715 & 26074 & 25366 & 25715 & 25715 & 25715 & 25715 & 26074 & 25366 & 25715 & 25715 & 23544 & 27885 & 24827 & 26580 \\
\hline & Bodemoverschot & Overschot per ha: stikstof (kg N) & 139 & 139 & 139 & 142 & 136 & 139 & 139 & 139 & 139 & 139 & 139 & 146 & 132 & 142 & 136 \\
\hline & & Overschot per ha: fosfaat (kg P2O5) & 11 & 11 & 11 & 11 & 11 & 11 & 10 & 11 & 11 & 16 & 6 & 11 & 11 & 11 & 10 \\
\hline & Ammoniak & Emissie per bedrijf: totaal (kg NH3) & 2855 & 2833 & 2877 & 2805 & 2906 & 2855 & 2855 & 2838 & 2872 & 2855 & 2855 & 2674 & 3036 & 2787 & 2920 \\
\hline & Broeikasgassen & Emissie per ton melk: totaal bedrijf (kg CO2-eq) & 1110 & 1114 & 1106 & 1107 & 1112 & 1110 & 1110 & 1109 & 1111 & 1110 & 1110 & 1067 & 1152 & 1093 & 1126 \\
\hline \multirow[t]{8}{*}{9} & BEX & Voordeel bedrijfspecifiek excretie: stikstof & $0 \%$ & $0 \%$ & $0 \%$ & $4 \%$ & $-3 \%$ & $0 \%$ & $0 \%$ & $0 \%$ & $0 \%$ & $0 \%$ & $0 \%$ & $7 \%$ & $-6 \%$ & $2 \%$ & $-2 \%$ \\
\hline & & Voordeel bedrijfspecifiek excretie: fosfaat & $-17 \%$ & $-17 \%$ & $-17 \%$ & $-17 \%$ & $-17 \%$ & $-13 \%$ & $-21 \%$ & $-17 \%$ & $-17 \%$ & $-20 \%$ & $-14 \%$ & $-9 \%$ & $-25 \%$ & $-15 \%$ & $-19 \%$ \\
\hline & Opbrengst grasland & Opbrengst netto per ha: droge stof ( $\mathrm{kg} \mathrm{ds}$ ) & 7197 & 7485 & 6944 & 7197 & 7197 & 7197 & 7197 & 7166 & 7226 & 7197 & 7197 & 6679 & 7716 & 6998 & 7391 \\
\hline & Opbrengst maisland & Opbrengst netto per ha: droge stof ( $\mathrm{kg} \mathrm{ds}$ ) & 9363 & 9567 & 9167 & 9363 & 9363 & 9363 & 9363 & 9567 & 9167 & 9363 & 9363 & 8758 & 9960 & 9104 & 9615 \\
\hline & Bodemoverschot & Overschot per ha: stikstof (kg N) & 67 & 70 & 64 & 69 & 65 & 67 & 67 & 68 & 66 & 67 & 67 & 65 & 69 & 67 & 67 \\
\hline & & Overschot per ha: fosfaat (kg P2O5) & 19 & 19 & 18 & 19 & 19 & 19 & 19 & 19 & 18 & 21 & 16 & 18 & 20 & 19 & 18 \\
\hline & Ammoniak & Emissie per bedrijf: totaal (kg NH3) & 6157 & 6104 & 6211 & 5889 & 6427 & 6157 & 6157 & 6126 & 6187 & 6157 & 6157 & 5682 & 6633 & 5994 & 6315 \\
\hline & Broeikasgassen & Emissie per ton melk: totaal bedrijf ( $\mathrm{kg} \mathrm{CO} 2-\mathrm{eq})$ & 1397 & 1416 & 1380 & 1388 & 1407 & 1397 & 1397 & 1399 & 1395 & 1397 & 1397 & 1339 & 1456 & 1374 & 1419 \\
\hline
\end{tabular}




\begin{tabular}{|c|c|c|c|c|c|c|c|c|c|c|c|c|c|c|c|c|c|}
\hline \multirow[t]{2}{*}{ Bedrijf } & \multicolumn{2}{|r|}{ Kengetallen Kringloopwijzer } & \multicolumn{15}{|c|}{ Parameter } \\
\hline & & & 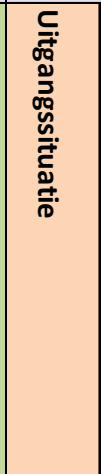 & 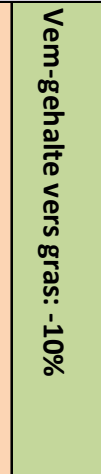 & 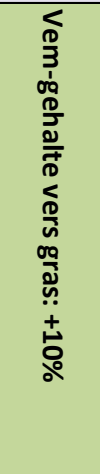 & 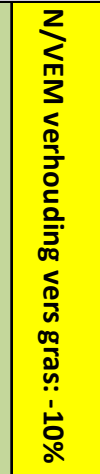 & 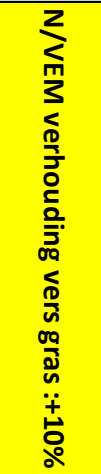 & 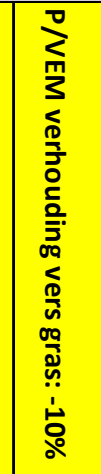 & 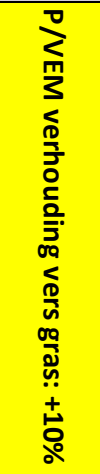 & 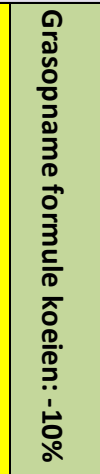 & 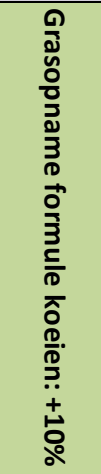 & 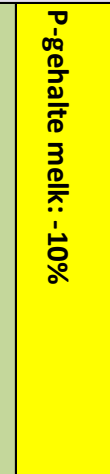 & 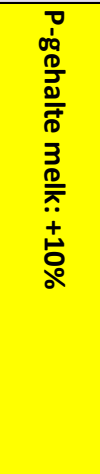 & 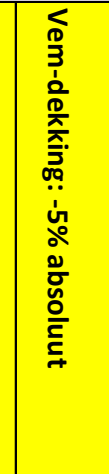 & 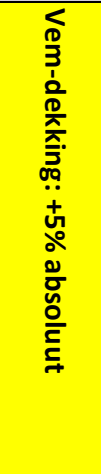 & 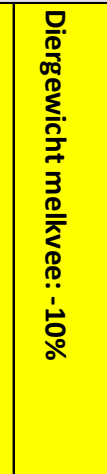 & 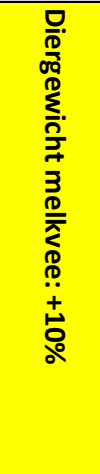 \\
\hline \multirow[t]{8}{*}{10} & BEX & Voordeel bedrijfspecifiek excretie: stikstof & $-1 \%$ & $-1 \%$ & $-1 \%$ & $0 \%$ & $-2 \%$ & $-1 \%$ & $-1 \%$ & $-1 \%$ & $-1 \%$ & $-1 \%$ & $-1 \%$ & $5 \%$ & $-7 \%$ & $1 \%$ & $-3 \%$ \\
\hline & & Voordeel bedrijfspecifiek excretie: fosfaat & $13 \%$ & $14 \%$ & $13 \%$ & $13 \%$ & $13 \%$ & $14 \%$ & $13 \%$ & $14 \%$ & $13 \%$ & $10 \%$ & $17 \%$ & $19 \%$ & $8 \%$ & $15 \%$ & $12 \%$ \\
\hline & Opbrengst grasland & Opbrengst netto per ha: droge stof ( $\mathrm{kg} \mathrm{ds})$ & 12423 & 12554 & 12294 & 12423 & 12423 & 12423 & 12423 & 12414 & 12432 & 12423 & 12423 & 11512 & 13334 & 12074 & 12763 \\
\hline & Opbrengst maisland & Opbrengst netto per ha: droge stof (kg ds) & 28047 & 28345 & 27757 & 28047 & 28047 & 28047 & 28047 & 28345 & 27757 & 28047 & 28047 & 25990 & 30105 & 27260 & 28816 \\
\hline & Bodemoverschot & Overschot per ha: stikstof (kg N) & 77 & 78 & 77 & 78 & 76 & 77 & 77 & 78 & 77 & 77 & 77 & 81 & 73 & 79 & 75 \\
\hline & & Overschot per ha: fosfaat (kg P2O5) & -28 & -28 & -28 & -28 & -28 & -28 & -28 & -28 & -28 & -24 & -32 & -29 & -27 & -27 & -29 \\
\hline & Ammoniak & Emissie per bedrijf: totaal (kg NH3) & 3322 & 3300 & 3345 & 3265 & 3380 & 3322 & 3322 & 3304 & 3339 & 3322 & 3322 & 3069 & 3576 & 3244 & 3398 \\
\hline & Broeikasgassen & Emissie per ton melk: totaal bedrijf (kg CO2-eq) & 1364 & 1369 & 1359 & 1361 & 1367 & 1364 & 1364 & 1364 & 1364 & 1364 & 1364 & 1309 & 1419 & 1344 & 1384 \\
\hline \multirow[t]{8}{*}{11} & BEX & Voordeel bedrijfspecifiek excretie: stikstof & $5 \%$ & $5 \%$ & $4 \%$ & $5 \%$ & $4 \%$ & $5 \%$ & $5 \%$ & $5 \%$ & $4 \%$ & $5 \%$ & $5 \%$ & $10 \%$ & $-1 \%$ & $6 \%$ & $3 \%$ \\
\hline & & Voordeel bedrijfspecifiek excretie: fosfaat & $4 \%$ & $4 \%$ & $4 \%$ & $4 \%$ & $4 \%$ & $4 \%$ & $3 \%$ & $4 \%$ & $4 \%$ & $1 \%$ & $7 \%$ & $9 \%$ & $-2 \%$ & $5 \%$ & $3 \%$ \\
\hline & Opbrengst grasland & Opbrengst netto per ha: droge stof ( $\mathrm{kg} \mathrm{ds})$ & 8740 & 8809 & 8672 & 8740 & 8740 & 8740 & 8740 & 8708 & 8771 & 8740 & 8740 & 8036 & 9444 & 8462 & 9011 \\
\hline & Opbrengst maisland & Opbrengst netto per ha: droge stof (kg ds) & 16560 & 16691 & 16431 & 16560 & 16560 & 16560 & 16560 & 16691 & 16431 & 16560 & 16560 & 15226 & 517894 & 16033 & 17074 \\
\hline & Bodemoverschot & Overschot per ha: stikstof (kg N) & 158 & 158 & 157 & 158 & 157 & 158 & 158 & 158 & 157 & 158 & 158 & 159 & 156 & 159 & 156 \\
\hline & & Overschot per ha: fosfaat (kg P2O5) & 16 & 16 & 16 & 16 & 16 & 16 & 16 & 16 & 16 & 19 & 13 & 15 & 17 & 17 & 16 \\
\hline & Ammoniak & Emissie per bedrijf: totaal (kg NH3) & 1899 & 1889 & 1910 & 1878 & 1921 & 1899 & 1899 & 1891 & 1907 & 1899 & 1899 & 1774 & 2024 & 1864 & 1933 \\
\hline & Broeikasgassen & Emissie per ton melk: totaal bedrijf (kg CO2-eq) & 1686 & 1689 & 1683 & 1683 & 1689 & 1686 & 1686 & 1686 & 1686 & 1686 & 1686 & 1626 & 1746 & 1664 & 1708 \\
\hline
\end{tabular}

40 | Wageningen Livestock Research Rapport 1110 


\begin{tabular}{|c|c|c|c|c|c|c|c|c|c|c|c|c|c|c|c|c|c|}
\hline \multirow[t]{2}{*}{ Bedrijf } & \multicolumn{2}{|r|}{ Kengetallen Kringloopwijzer } & \multicolumn{15}{|c|}{ Parameter } \\
\hline & & & 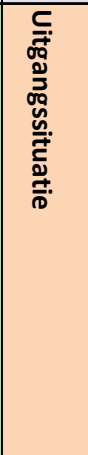 & 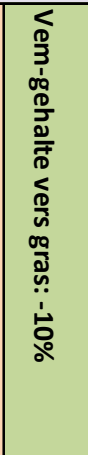 & 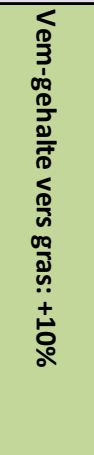 & 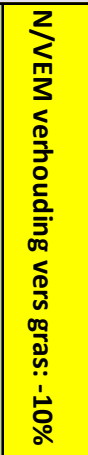 & 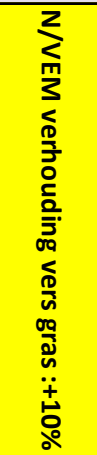 & 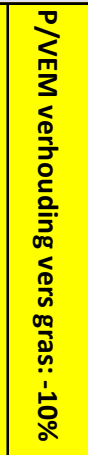 & 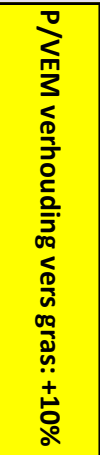 & 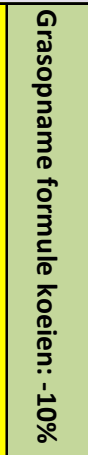 & 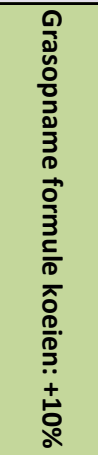 & 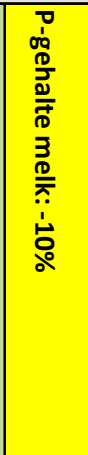 & 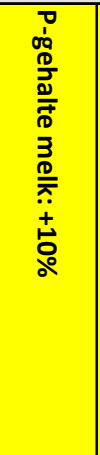 & 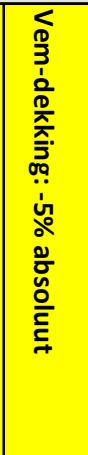 & 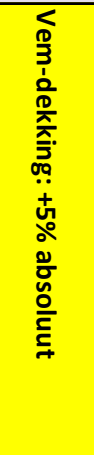 & 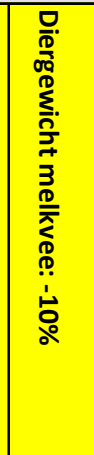 & 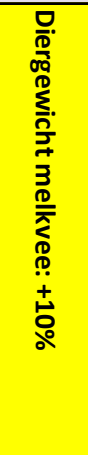 \\
\hline \multirow[t]{8}{*}{12} & BEX & Voordeel bedrijfspecifiek excretie: stikstof & $-13 \%$ & $-13 \%$ & $-13 \%$ & $-9 \%$ & $-17 \%$ & $-13 \%$ & $-13 \%$ & $-13 \%$ & $-13 \%$ & $-13 \%$ & $-13 \%$ & $-5 \%$ & $-21 \%$ & $-10 \%$ & $-16 \%$ \\
\hline & & Voordeel bedrijfspecifiek excretie: fosfaat & $-11 \%$ & $-11 \%$ & $-11 \%$ & $-11 \%$ & $-11 \%$ & $-7 \%$ & $-15 \%$ & $-11 \%$ & $-11 \%$ & $-14 \%$ & $-8 \%$ & $-3 \%$ & $-19 \%$ & $-8 \%$ & $-13 \%$ \\
\hline & Opbrengst grasland & Opbrengst netto per ha: droge stof ( $\mathrm{kg} \mathrm{ds}$ ) & 13026 & 13518 & 12579 & 13026 & 13026 & 13026 & 13026 & 13099 & 12956 & 13026 & 13026 & 12092 & 13957 & 12635 & 13407 \\
\hline & Opbrengst maisland & Opbrengst netto per ha: droge stof ( $\mathrm{kg} \mathrm{ds})$ & 0 & 0 & 0 & 0 & 0 & 0 & 0 & 0 & 0 & 0 & 0 & 0 & 0 & 0 & 0 \\
\hline & Bodemoverschot & Overschot per ha: stikstof ( $\mathrm{kg} \mathrm{N}$ ) & 218 & 218 & 218 & 221 & 215 & 218 & 218 & 217 & 219 & 218 & 218 & 225 & 211 & 221 & 215 \\
\hline & & Overschot per ha: fosfaat (kg P2O5) & -17 & -17 & -16 & -17 & -17 & -16 & -17 & -17 & -16 & -14 & -19 & -16 & -17 & -16 & -17 \\
\hline & Ammoniak & Emissie per bedrijf: totaal (kg NH3) & 5196 & 5153 & 5241 & 4967 & 5430 & 5196 & 5196 & 5176 & 5216 & 5196 & 5196 & 4820 & 5573 & 5057 & 5331 \\
\hline & Broeikasgassen & Emissie per ton melk: totaal bedrijf (kg CO2-eq) & 1793 & 1814 & 1774 & 1775 & 1811 & 1793 & 1793 & 1796 & 1791 & 1793 & 1793 & 1719 & 1868 & 1763 & 1822 \\
\hline \multirow[t]{8}{*}{13} & BEX & Voordeel bedrijfspecifiek excretie: stikstof & $-1 \%$ & $0 \%$ & $-1 \%$ & $2 \%$ & $-3 \%$ & $-1 \%$ & $-1 \%$ & $0 \%$ & $-1 \%$ & $-1 \%$ & $-1 \%$ & $6 \%$ & $-7 \%$ & $2 \%$ & $-3 \%$ \\
\hline & & Voordeel bedrijfspecifiek excretie: fosfaat & $-8 \%$ & $-8 \%$ & $-8 \%$ & $-8 \%$ & $-8 \%$ & $-6 \%$ & $-11 \%$ & $-8 \%$ & $-8 \%$ & $-12 \%$ & $-5 \%$ & $0 \%$ & $-16 \%$ & $-6 \%$ & $-10 \%$ \\
\hline & Opbrengst grasland & Opbrengst netto per ha: droge stof ( $\mathrm{kg} \mathrm{ds}$ ) & 11886 & 12199 & 11604 & 11886 & 11886 & 11886 & 11886 & 11912 & 11860 & 11886 & 11886 & 10995 & 12775 & 11554 & 12209 \\
\hline & Opbrengst maisland & Opbrengst netto per ha: droge stof (kg ds) & 9149 & 9292 & 9009 & 9149 & 9149 & 9149 & 9149 & 9292 & 9009 & 9149 & 9149 & 8503 & 9788 & 8894 & 9398 \\
\hline & Bodemoverschot & Overschot per ha: stikstof (kg N) & 207 & 207 & 207 & 209 & 205 & 207 & 207 & 206 & 207 & 207 & 207 & 213 & 200 & 210 & 203 \\
\hline & & Overschot per ha: fosfaat (kg P2O5) & 1 & 1 & 1 & 1 & 1 & 1 & 1 & 1 & 1 & 4 & -3 & 1 & 1 & 1 & 0 \\
\hline & Ammoniak & Emissie per bedrijf: totaal (kg NH3) & 4789 & 4760 & 4819 & 4648 & 4932 & 4789 & 4789 & 4772 & 4806 & 4789 & 4789 & 4445 & 5135 & 4673 & 4902 \\
\hline & Broeikasgassen & Emissie per ton melk: totaal bedrijf (kg CO2-eq) & 1454 & 1466 & 1443 & 1446 & 1462 & 1454 & 1454 & 1455 & 1453 & 1454 & 1454 & 1394 & 1514 & 1432 & 1475 \\
\hline
\end{tabular}



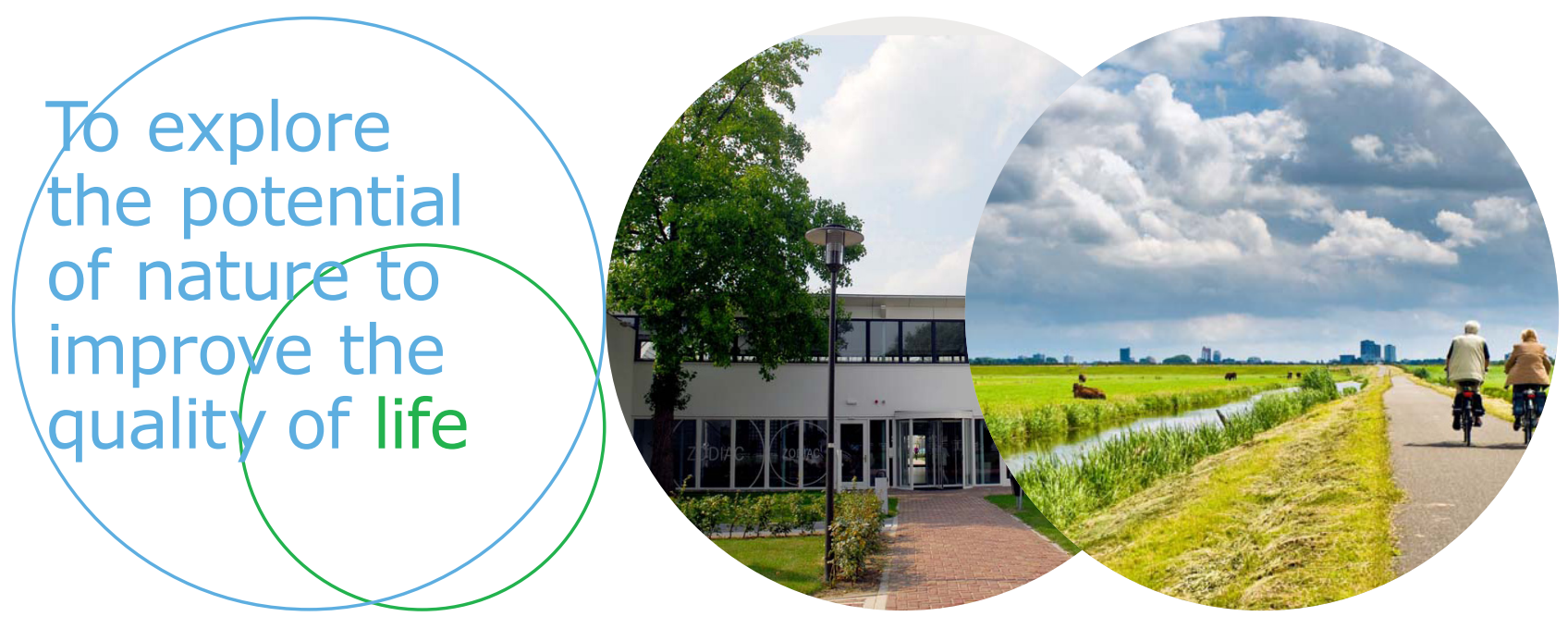

Wageningen Livestock Research Postbus 338

Wageningen Livestock Research ontwikkelt kennis voor een zorgvuldige en $6700 \mathrm{AH}$ Wageningen

T 0317483953

renderende veehouderij, vertaalt deze naar praktijkgerichte oplossingen en innovaties, en zorgt voor doorstroming van deze kennis. Onze wetenschappelijke E info.livestockresearch@wur.nl www.wur.nl/ livestock-research kennis op het gebied van veehouderijsystemen en van voeding, genetica, welzijn en milieu-impact van landbouwhuisdieren integreren we, samen met onze klanten, tot veehouderijconcepten voor de $21 \mathrm{e}$ eeuw.

De missie van Wageningen University \& Research is 'To explore the potential of nature to improve the quality of life'. Binnen Wageningen University \& Research bundelen 9 gespecialiseerde onderzoeksinstituten van Stichting Wageningen Research en Wageningen University hun krachten om bij te dragen aan de oplossing van belangrijke vragen in het domein van gezonde voeding en leefomgeving. Met ongeveer 30 vestigingen, 6.500 medewerkers en 10.000 studenten behoort Wageningen University \& Research wereldwijd tot de aansprekende kennisinstellingen binnen haar domein. De integrale benadering van de vraagstukken en de samenwerking tussen verschillende disciplines vormen het hart van de unieke Wageningen aanpak. 